\title{
MODEL KEMATIAN BIOTA AIR SEBAGAI FUNGSI WAKTU KONTAK PADA AIR LIMBAH DETERJEN DAN GAGASAN SEDERHANA PENGENDALIANNYA
}

\section{THE MODEL OF AQUATIC BIOTA MORTALITY AS A FUNCTION OF DETENTION TIME OF THE DETERGENT WASTEWATER AND SIMPLE IDEA FOR CONTROLLING}

\author{
Yuliya Mahdalena Hidayat \\ Balai Lingkungan Keairan Pusat Penelitian dan Pengembangan Sumber Daya Air \\ Jl. Ir. H. Juanda193 Bandung, Jawa Barat, Indonesia \\ E-mail: yuliya96_119@yahoo.com
}

Diterima: 2 Februari 2016; Direvisi: Februari 2016; Disetujui: 4 Maret 2016

\begin{abstract}
ABSTRAK
Residu pengunaan deterjen berupa limbah cair, berdampak negatif terhadap lingkungan, diantaranya toksid pada biota air. Model kematian biota air sebagai fungsi waktu kontak untuk konsentrasi deterjen pada air limbah yang diturunkan dari data sekunder, model diseleksi melalui pemilihan jenis trendline dengan koefisien determinasi yang paling tinggi sedangkan gagasan sederhana teknik pengendalian pencemaran deterjen dianalisis dari penelitian sebelumnya dan beberapa aspek lainnya. Hasil menunjukkan, banyaknya kematian biota air dengan waktu pengamatan dapat dinyatakan dengan model polynominal orde dua. Kerusakan organ vital biota seperti membran sel, jantung dan hati, serta turunnya kualitas air di duga kuat menjadi penyebab kematian organisme air akibat peningkatan deterjen pada badan air. Konsentrasi deterjen yang sangat tinggi, membahayakan biota dalam badan air. Penggunaan deterjen ramah lingkungan, serta pengolahan limbah cair deterjen sebelum masuk ke badan air diharapkan bisa lebih melindungi biota air, sehingga ekosistem tetap terjaga. Gagasan teknik penyaringan deterjen individu (TPDI) diharapkan bisa diterima dan dimanfaatkan masyarakat sebagai salah satu pengendalian pencemaran deterjen.
\end{abstract}

Kata Kunci: Deterjen, model, kematian biota air, koefisien determinasi,teknik penyaringan deterjen individu

\section{ABSTRACT}

Wastewater is a residual from detergents usage that has negative impact to the environment, such as aquatic biota toxid. The Model of aquatic biota mortality as a function of detention time for the wastewater detergent concentration was eliminated by scondary data, model is selected by election of trendline type that have highest determination coefficient, while simple idea of the detergent pollution control technique was analised from previous research and some other aspect. Result showed that aquatic biota mortality with perception time can be expressed with scond order polynominal model. Damage of the vital aquatic biota organ such as cell membran,liver and heart and also water quality degradation is allegedly caused of organisms mortality as a due to detergent increased in water bodies. A very high detergent concentration, is endangering biota in water bodies. Usage of environmentally friendy detergens, and also wastewater treatment for detergent before entering the water bodies, is expected to protecting more aquatic biota so that ecosystem can maintained. Individual deregent screening technique (TPDI) idea expected acceptable and exploted by public as one of the detergent pollution control.

Keywords: Detergent, model, aquatic biota mortality, determination coefficient, individual deregent screening technique

\section{PENDAHULUAN}

Penggunaan deterjen pada seluruh lapisan masyarakat semakin meningkat seiring dengan pertumbuhan penduduk terutama untuk bahan pembersih dalam kehidupan sehari hari. Data hasil penelitian (Lubis dkk, 2014) menyebutkan penggunaan deterjen perkapita rata rata sebesar 8,22 kg sejalan dengan pertumbuhan gross 
domestic product (GDP) setiap tahun. Sementara itu, produksi deterjen di dunia sekitar 10juta ton/ tahun (IMRG 2012; Uc-Peraza and Delgado-Blas, 2015). Komponen utama deterjen, surfaktan yang berfungsi sebagai zat aktif permukaan, diproduksi di dunia dengan total produksi tahunan diperkirakan melebihi 15 juta ton (Henkel et al. 2012).

Penggunaan deterjen dalam kehidupan sehari - hari, pada akhirnya akan menghasilkan residu berupa limbah cair. Limbah cair deterjen ini, banyak dihasilkan dari air buangan domestik misalnya air bekas mandi, bekas cuci pakaian, perabotan rumah tangga serta jasa pencucian komersial, buangan industri kecil, pewarnaan industri kosmetik, dll. Limbah cair deterjen mempunyai potensi negatif terhadap lingkungan seperti mencemari tanah dan sumber air bagi mahluk hidup(Budiawan dkk, 2009), mengganggu kehidupan organisme air (Garno, 2000) serta menghambat transfer oksigen pada badan perairan (Chaerunisah dan Sopiah, 2006).

Publikasi tentang beberapa sumber air di DKI Jakarta dalam beberapa tahun ini telah terkontaminasi deterjen merupakan bukti pengaruh negatif limbah cair deterjen terhadap lingkungan. Telah terjadi peningkatan konsetrasi deterjen di Sungai Ciliwung, mulai masuk wilayah Jakarta Selatan hingga Jakarta Utara dari tahun 1999 -2004, dan konsentrasi tertinggi di tahun 2003 dimungkinkan kondisi sungai yang pekat akibat nilai rata rata hujan pada tahun 2003 sangat rendah (Yudo, 2010). Sejumlah air baku di DKI Jakarta lebih banyak tercemar limbah rumah tangga, misalnya kandungan deterjen air baku di IPA (Instalasi Pengolahan Air) Cilandak mencapai 1,2 ppm, prosentase pencemaran terbesar di Sungai Ciliwung sebagai sumber bahan baku PDAM Depok berasal dari limbah domestik selain limbah cair rumah tangga juga limbah cair laundry(Sinar harapan, 2015)

Pengaruh deterjen terhadap lingkungan dapat diketahui melalui uji biologis (Hardini, 2012). Penelitian pengaruh deterjen terhadap lingkungan melalui uji biologis umumnya dilakukan dengan uji toksisitas deterjen terhadap kematian biota air. Penelitian - penelitian tersebut, diantaranya dilakukan terhadap Chiromus sp, Daphnia Carinata dan Culex sp (Garno, 2000); Cyprinus Carpio L (Halang, 2004; Pratiwi dkk, 2012; Lubis, 2014); Orheochromis Niloticus (Hardini dkk, 2012 ; Aini, 2013).

Penelitian uji toksisitas deterjen terhadap kematian biota air sudah banyak dilakukan, namun penelitian tentang persamaan matematis toksisitas deterjen terhadap biota air masih jarang. Dengan adanya persamaan matematetis maka didapat suatu model yang berguna untuk memperkirakan kecenderungan toksisitas deterjen terhadap biota. Jika terjadi gangguan yang serius terhadap biota dan badan air berdasarkan model tersebut maka perlu di identifikasi upaya pengendaliannya, sehingga penelitian ini juga mencoba merumuskan gagasan teknik pengendalian pencemaran deterjen sederhana yang bisa diterapkan di masyarakat. Penelitian sebelumnya tentang upaya pengendalian pencemaran deterjen telah banyak dilakukan, yaitu fitroremediasi (Hermawati dkk, 2005); pengolahann kimia (Pratiwi dkk, 2012); filter aerasi kontak (Said dan Marsidi, 2004) dan filter keramik (Nasir dan Budi, 2011), tetapi gagasan teknik pengendalian pencemaran deterjen sederhana menggunakan absorban arang aktif yang dapat diterima masyarakat masih jarang.

Tujuan dari penelitian ini adalah memformulasikan persamaan matematis hubungan antara banyaknya kematian biota air dengan waktu pengamatan akibat air limbah deterjen, dan menganalisis upaya pengendalian pencemaran deterjen sebelumnya serta merumuskan gagasan teknik pengendalian pencemaran deterjen sederhana.

\section{KAJIAN PUSTAKA}

\section{Deterjen}

Deterjen sebagai bahan pembersih yang digunakan untuk membersihkan kotoran pada pakaian, perabotan rumah tangga atau untuk menghilangkan kotoran pada benda - benda lainnya (Said dan Marsidi, 2004), merupakan hasil samping penyulingan minyak bumi, ditambah bahan kimia lainnya seperti fosfat, silikat, bahan pewarna dan bahan pewangi (Hardini, 2012). Deterjen, mengandung sekitar 25 macam bahan (ingredient) yang dikelompokan menjadi surfaktan, builder, bleaching agents dan additives (Smulders, 2002).

Surfaktan merupakan senyawa yang larut dalam air, dibedakan atas surfaktan anionik, surfaktan nonionik, surfaktan kationik dan surfaktan amfoterik (Nasir dan Budi, 2011). Jenisjenis surfaktan yang terdapat dalam deterjen dapat dilihat pada Tabel 1.

Surfaktan anionik adalah zat yang menghasilkan ion muatan negatif dalam larutan, terdiri dari grup sulfonat, sulfat atau karboksilat (Said dan Marsidi, 2004). Linear Alkylbenzene Sulfonate (LAS) banyak digunakan menggantikan Alkyl Benzena Sulphonate (ABS) karena relatif mudah terurai di dalam air. LAS merupakan senyawa surfaktan anionik yang banyak digunakan 
dalam deterjen, digunakan di Negara Asia Pasific dan Amerika Latin, (Nasir dan Budi, 2011).

Surfaktan nonionik mengandung grup hydrophilic (gugus yang mudah terionisasi dalam air) yang tidak terionisasi dalam larutan. Salah satu contoh surfaktan ini yang paling komersil adalah yang mengandung grup polyether hydophobe yang merupakan turunan ethylene oxide (Said dan Marsidi, 2004). Grup hidrophilic merupakan gugus yang mudah larut dalam air.

Surfaktan kationik adalah zat yang menghasilkan ion muatan positif dalam larutan, menarik perhatian karena sifat bactericidal atau germicidalnya, sehingga digunakan sebagai zat cuci hama untuk pencuci alat rumah tangga manakala tidak tersedia air panas (Said dan Marsidi, 2004). Akan tetapi sebagai deterjen, zat ini kurang disukai karena harganya yang mahal. Salah satu contoh surfaktan kationik adalah turunan ammonium quartenary.

Surfaktan amfoterik adalah surfaktan yang di desain dengan variasi yang mempunyai sifat khusus dan digunakan untuk keperluan khusus, diproduksi dalam jumlah relatif kecil (Said dan Marsidi, 2004). Sifat khusus surfaktan amfoterik yaitu mengandung muatan positif dan negatif pada bagian aktif permukaannya misalnya sulfobetain(Tang dan Suendo, 2011). Surfaktan ini biasanya khusus digunakan untuk kosmetik, shampo bayi dan produk pembersih lain yang memerlukan kelembutan.

Builder merupakan zat penunjang kinerja deterjen dalam pelunakan air (softnening) dengan cara membatasi kerja ion-ion kalsium dan magnesium. Builder dapat berupa senyawa alkali yang mudah mengendap seperti natrium karbonat dan natrium silikat; agen kompleks seperti Natrium Triphosfat atau asam nitroloacetic dan senyawa bersifat penukar ion seperti asam polikarboksilat dan zeolit A (Nasir dan Budi, 2011).

Bleaching effect (Efek pemucatan) dari deterjen ditimbulkan melalui cara mekanis, fisika dan/atau secara kimia khususnya melalui perubahan atau penyisihan zat pewarna terhadap objek yang mengalami proses pemucatan. Efek pemucatan dapat ditimbulkan secara parallel dalam proses pencucian (Nasir dan Budi, 2011). Mekanisme mekanis dan fisis utamanya efektif untuk menghilangkan partikulat atau zat-zat yang mengandung oli. Pemucatan secara kimia dilakukan untuk menghilangkan warna dan karat yang melekat pada serat (Nasir dan Budi, 2011).

Bleaching agent yang banyak digunakan biasanya adalah senyawa-senyawa peroksida. Hidrogen Peroksida terkonversi menjadi anion hidroksida intermediate aktif dalam media alkali menjadi menurut persamaan reaksi (Nasir dan Budi, 2011) :

$$
\mathrm{H}_{2} \mathrm{O}_{2}+\mathrm{OH}^{-} \leftrightarrows \mathrm{H}_{2} \mathrm{O}+\mathrm{HO}_{2}^{-}
$$

Anion-anion perhidroksil dapat mengoksidasi pengotor padat dan karat. Senyawa perhidroksil pada deterjen diantaranya Natrium Perborat $\left(\mathrm{NaBO}_{3} \cdot 4 \mathrm{H}_{2} \mathrm{O}\right)$ dan hipoklorit (klorin). Keunggulan utama natrium perborat dapat dimasukan langsung sebagai bubuk dengan hasil cucian yang putih dan relatif aman. Sebaliknya, larutan pemutih klorin dalam konsentrasi tinggi dapat menyebabkan kerusakan signifikan dan menyebabkan perubahan warna. Klorin cukup efektif digunakan sebagai pemutih dan disinfektan pada suhu yang rendah (Nasir dan Budi, 2011).

Tabel 1 Jenis-jenis surfaktan dalam deterjen

\begin{tabular}{|c|c|c|c|}
\hline No & Surfaktan & Rumus Bangun & $\begin{array}{l}\text { Jenis } \\
\text { surfaktan }\end{array}$ \\
\hline 1 & Alkil (polietilen)glikol ethers & $\mathrm{RO}-\left(\mathrm{CH}_{2}-\mathrm{CH}_{2}-\mathrm{O}\right)_{n} \mathrm{H}$ & Non ionik \\
\hline 2 & Alkilsulfonat & $\mathrm{F}-\mathrm{SO}_{\mathbf{3}} \mathrm{Na}^{+}$ & Anionik \\
\hline 3 & $\begin{array}{l}\text { Dialkildimetilamonium } \\
\text { chlorida }\end{array}$ & {$\left[\begin{array}{c}\mathbf{R} \\
1 \\
\mathrm{H}_{3} \mathrm{C}-\mathrm{N}^{\mathrm{N}} \pm \mathrm{CH}_{3} \\
\mathbf{R}\end{array}\right] \mathrm{Cl}^{-}$} & Kationik \\
\hline 4 & Betaines & 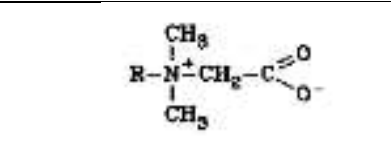 & Amfoterik \\
\hline
\end{tabular}


Aditif merupakan bagian terkecil dari deterjen, dapat berupa enzim, senyawa anti redeposisi seperti Carboxyl Methyl Cellulose (CMC), Carboxyl Methyl Starch (CMS), senyawa pengatur busa (foam regulator) seperti Fatty Acid Amides, Fatty Acid Alkanolamine. Hasil cucian yang wangi, dapat ditambahkan fragrance dan zat warna sesuai dengan yang diinginkan serta bahan pengisi lainnya/filler (Nasir dan Budi, 2011).

\section{Jenis biota yang diteliti}

\subsection{Chironomous sp}

Chironomous sp merupakan sejenis serangga yang tergolong famili Chironomidae (Shafruddin, dkk, 2006), memiliki habitat di perairan yang kaya bahan organik (Arimoro, et al., 2007). Famili Chironomidae menjadi $10-15 \%$ biomassa makroinvebrata air yang masing-masing subfamily maupun ordonya memiliki preferensi tertentu terhadap kondisi suatu lingkungan perairan (Odume \& Muller, 2011; Fardhani dkk, 2014), merespon cepat perubahan kondisi perairan(Heinrich et al., 2006), sehingga dapat digunakan untuk indikator pencemaran.

\subsection{Daphnia carinata}

Daphnia carinata (D. carinata) adalah salah satu jenis zooplankton kladosera dari genus Daphnia, banyak ditemukan di perairan tawar, hidup dengan memakan fitoplankton, bakteria dan detritus disekitarnya melalui proses penyaringan/filtering rate (Garno, 2000).

Sifat-sifat Daphnia yang tersebar luas di berbagai perairan tawar, mudah ditangkap, mempunyai species yang banyak, berukuran sedang, gampang dipelihara dan dikembang biakan (Benardi and Peters, 1987 dalam Garno, 2000) membuat Daphnia menjadi salah satu hewan uji terbaik untuk mengetahui pengaruh suatu bahan pencemar dalam perairan tawar (Garno, 2000).

\subsection{Culex sp}

Culex sp adalah sejenis nyamuk dengan 2 buah sayap, banyak ditemukan didaerah tropis pada badan-badan air menggenang, dan dapat tinggal dengan tenang dibawah permukaan air dan berenang jika mendapat gangguan (Pennak, 1953 dalam Garno, 2000). Larva Culex sp. umumnya memakan fitoplankton yang ada dalam badan air (Garno, 2000).

\subsection{Cyprinus carpio $L$}

Cyprinus cario $L$ atau dikenal dengan ikan mas, merupakan jenis ikan air tawar yang mempunyai tingkat komsumsi yang cukup tinggi. Cyprinus cario $L$ mempunyai kepekaan yang tinggi terhadap perubahan lingkungan (Lubis dkk, 2014), dan saat dibudidayakan dapat berkembang optimum pada suhu $26-30^{\circ} \mathrm{C}$ (Arifin dkk, 2007 dalam Putranti dkk, 2015), dan DO berkisar antara 3 - $5 \mathrm{mg} / \mathrm{L}$ (Zonneved et al., 1991 dalam Putranti dkk, 2015).

\subsection{Orheochromis niloticus}

Orheochromis Miloticus atau dikenal dengan ikan nila, merupakan salah satu ikan air tawar yang cukup berkembang di Indonesia selain ikan mas (Noviantoro, dkk, 2015). Ikan Nila dapat dipelihara optimum pada suhu $25-30^{\circ} \mathrm{C}$, DO berkisar antara $3-5 \mathrm{mg} / \mathrm{L}$ dan $\mathrm{pH}$ berkisar 5-8 (Ath-thar dkk, 2010).

\section{METODOLOGI}

Penelitian dilakukan selama bulan Desember 2015 - Januari 2016. Jenis data yang digunakan untuk mendapatkan persamaan matematis hubungan banyaknya kematian biota air dengan waktu pengamatan akibat konsentrasi air limbah deterjen berupa data sekunder. Data - data tersebut (Tabel 2) sebelumnya pernah digunakan dalam penelitian sebelumnya (Garno, 2000; Halang, 2004; Hermawati dkk, 2005; Pratiwi dkk, 2012; Hardini dkk, 2012; Lubis dkk, 2014 ) yang dikembangkan untuk keperluan analisis lebih mendalam sesuai tujuan penelitian ini. Adapun jenis instrument data, sumber data, judul tulisan, tahun penulisan, dan Nama penulis jurnal dapat dilihat pada Tabel 2 .

Hubungan banyaknya biota air yang mati dengan waktu pengamatan setelah peningkatan konsentrasi deterjen dipengaruhi beberapa instrument data, yaitu : konsentrasi deterjen atau limbah laundry, jenis organisme, jumlah organisme dan waktu kematian organisme. Waktu pengamatan dari penelitian - penelitian ini berbeda - beda, sehingga untuk waktu pengamatan dikonversikan dahulu ke waktu pengamatan yang terendah pada penelitian - penelitian tersebut yaitu menggunakan satuan waktu menit. Hubungan tersebut dibuat dalam grafik yang kemudian ditentukan jenis trendlinenya.

Pembuatan persamaan untuk menyatakan hubungan kematian biota air dengan waktu, diseleksi melalui pemilihan jenis trendline yang koefisien korelasi $\left(\mathrm{R}^{2}\right)$ paling tinggi, berdasarkan interpretasi koefisien korelasi pada Tabel 3.

Data sekunder yang terdiri dari \%(persentase) konsentrasi deterjen dan beberapa nilai parameter kualitas air pada no. 5 dan 6 pada Tabel 2 digunakan untuk mendapatkan verifikasi/validasi pengaruh deterjen terhadap kematian biota air.

Upaya pengendalian pencemaran deterjen sebelumnya di analisis berdasarkan data sekunder dari penelitian sebelumnya yaitu Hermawati dkk, 2005; Pratiwi dkk, 2012; Said dan Marsidi, 2004 dan Nasir dan Budi, 2011. Efisiensi penyisihan 
limbah cair deterjen dari keempat penelitan tersebut dijadikan dasar untuk menemukan gagasan teknik pengendalian pencemaran deterjen sederhana skala individual pada sumbernya baik berupa teknik maupun media yang digunakan.
Gagasan teknik pengendalian pencemaran deterjen sederhana di analisis kemugkinannya berdasarkan beberapa aspek berdasarkan keberteriman dan kemanfaatan di masyarakat pada umumnya serta efisiensi terhadap lingkungan terhadap badan air penerimanya.

Tabel 2 Data sekunder yang digunakan dalam penelitian

\begin{tabular}{|c|c|c|c|c|c|}
\hline No & Jenis Instrumen Data & Sumber Data & Judul Tulisan & Tahun & Nama Penulis \\
\hline 1 & $\begin{array}{l}\text { - Konsentrasi deterjen(rinso) } \\
\text { - Jenis organisme (Chiromus } \\
\text { sp, Daphnia carinata dan } \\
\text { Larva Culex sp) } \\
\text { - Jumlah organisme } \\
\text { - Waktu kematian organisme }\end{array}$ & $\begin{array}{l}\text { Jurnal Teknik } \\
\text { Lingkungan } \\
\text { Volume } 1 \text { No. } 3\end{array}$ & $\begin{array}{l}\text { Daya Tahan Beberapa } \\
\text { Organisme Air pada } \\
\text { Pencemar Deterjen }\end{array}$ & 2000 & $\begin{array}{l}\text { Yudhi Soetrisno Garno, } \\
\text { PhD }\end{array}$ \\
\hline 2 & $\begin{array}{l}\text { - Konsentrasi Limbah Laundry } \\
\text { - Jenis organisme : } \\
\text { Cyprinus carpio L } \\
\text { - Jumlah organisme } \\
\text { - Waktu kematian organisme }\end{array}$ & $\begin{array}{l}\text { Prosiding Seminar } \\
\text { Nasional Aplikasi } \\
\text { Sains dan } \\
\text { Teknologi (SNAST) } \\
\text { Periode III, ISSN : } \\
\text { 1979-911X }\end{array}$ & $\begin{array}{l}\text { Uji Toksisitas Limbah } \\
\text { Cair Laundry Sebelum } \\
\text { dan Sesudah Diolah } \\
\text { dengan Tawas dan } \\
\text { Karbon Aktif dengan } \\
\text { Bioindikator (Cyprinus } \\
\text { Carpio } L \text { ) }\end{array}$ & 2012 & $\begin{array}{l}\text { - Yuli Pratiwi } \\
\text { - Sri Sunarsih } \\
\text { - Winda Febria Windi }\end{array}$ \\
\hline 3 & $\begin{array}{l}\text { - Konsentrasi deterjen } \\
\text { - Jenis organisme : } \\
\text { Orheochromis niloticus } \\
\text { - Jumlah organisme } \\
\text { - Waktu kematian organisme }\end{array}$ & $\begin{array}{l}\text { Jurnal Perikanan } \\
\text { dan Kelautan Vol } \\
3 \text { No. 1, Maret } \\
\text { 2012: 59-63 }\end{array}$ & $\begin{array}{l}\text { Pengaruh Konsentrasi } \\
\text { Pemaparan Surfaktan } \\
\text { Alkyl Benzene Sulfonate } \\
\text { Terhadap Toksisitas dan } \\
\text { Kerusakan Jaringan Ikan } \\
\text { Nila }\end{array}$ & 2012 & $\begin{array}{l}\text { - Dwi Cindanita Hardini } \\
\text { - Yayat Dhahiyat } \\
\text { - Eddy Afrianto }\end{array}$ \\
\hline 4 & $\begin{array}{l}\text { - Konsentrasi deterjen (Rinso } \\
\text { Anti Noda) } \\
\text { - Jenis organisme : } \\
\text { Cyprinus Carpio L } \\
\text { - Jumlah organisme } \\
\text { - Waktu Kematian organisme }\end{array}$ & $\begin{array}{l}\text { Jurnal } \\
\text { Bioscientiae } \\
\text { Volume } 1 \text { Januari } \\
2004\end{array}$ & $\begin{array}{l}\text { Toksisitas Air Limbah } \\
\text { Deterjen terhadap Ikan } \\
\text { Mas }\end{array}$ & 2004 & Bunda Halang \\
\hline 5 & $\begin{array}{l}\text { - \% Konsentrasi deterjen } \\
\text { - Nilai Parameter terhadap } \\
\text { perubahan konsentrasi : DO } \\
\text { (mg/L), pH, dan Suhu }\left({ }^{0} \mathrm{C}\right)\end{array}$ & $\begin{array}{l}\text { Jurnal Biosmart } \\
\text { Volume } 7 \text {, Nomor } \\
2 \text { Halaman 115- } \\
124\end{array}$ & $\begin{array}{l}\text { Fitroremediasi Limbah } \\
\text { Deterjen Menggunakan } \\
\text { Kayu Apu (Pistia } \\
\text { stratiotes L.) dan Genjer } \\
\text { (Limnochoris flava L) }\end{array}$ & 2005 & $\begin{array}{l}\text { - Ervina Hermawati } \\
\text { - Wiryanto } \\
\text { - Solichatun }\end{array}$ \\
\hline 6 & $\begin{array}{l}\text { - Konsentrasi deterjen } \\
\text { - Jenis organisme : } \\
\text { Cyprinus Carpio L } \\
\text { - Jumlah organisme } \\
\text { - Waktu kematian organisme } \\
\text { - Nilai Parameter terhadap } \\
\text { perubahan konsentrasi : DO } \\
\text { (mg/L), pH dan Suhu }\left({ }^{\circ} \mathrm{C}\right)\end{array}$ & $\begin{array}{l}\text { Jurnal } \\
\text { Aquacoastmarine } \\
\text { Volume 4, Nomor } \\
3 \text { Halaman } 69-75 \text {, } \\
\text { Desember } 2014\end{array}$ & $\begin{array}{l}\text { Uji Deterjen terhadap } \\
\text { Ikan Mas }\end{array}$ & 2014 & $\begin{array}{l}\text { - Siti Devi Permata Sari } \\
\text { Lubis } \\
\text { - Budi Utomo } \\
\text { - Riri Ezraneti }\end{array}$ \\
\hline
\end{tabular}

Tabel 3 Interpretasi koefisien korelasi

\begin{tabular}{c|c}
\hline Interval Koefisien & Tingkat Hubungan \\
\hline $0,00-0,199$ & Sangat Rendah \\
\hline $0,20-0,399$ & Rendah \\
\hline $0,40-0,599$ & Sedang \\
\hline $0,60-0,799$ & Kuat \\
\hline $0,80-1,000$ & Sangat Kuat \\
\hline
\end{tabular}

Sumber : Sugiyono, 2011

\section{HASIL DAN PEMBAHASAN}

\section{Korelasi Konsentrasi dan Kematian Organisme}

Biota air yang akan dianalisis berdasarkan data sekunder yang ada dikelomokkan menjadi 5 jenis organisme, yaitu Chiromus sp, Daphnia carinata, Culex sp, Cyprinus carpio L dan Orheochromis nilaticus. Waktu pengamatan yang dilakukan untuk Chiromus sp, Daphnia carinata dan Culex sp (Garno, 2000) adalah menit ke : 90; 135; 220; 220; 
$310 ; 480 ; 700 ; 1030 ; 1560 ; 2320 ; 3490 ; 4320$, sedangkan konsentrasi deterjen(ppm) yang digunakan: $0 ; 0,01 ; 0,1 ; 1 ; 10 ; 100$ untuk Chiromus sp dan Daphnia carinata, serta konsentrasi deterjen(ppm) yang digunakan: $0 ; 225 ; 408 ; 643$; 103; 165 untuk Culex sp. Jumlah organisme yang digunakan untuk ketiga biota air tersebut masing masing konsentrasi sebanyak 30 ekor.
Hubungan antara jumlah organisme yang mati dengan waktu pengamatan (waktu kontak organisme terhadap deterjen) adalah sebagai berikut : Chiromus sp (Gambar 1), Daphnia carinata (Gambar 2), dan Culex sp (Gambar 3).

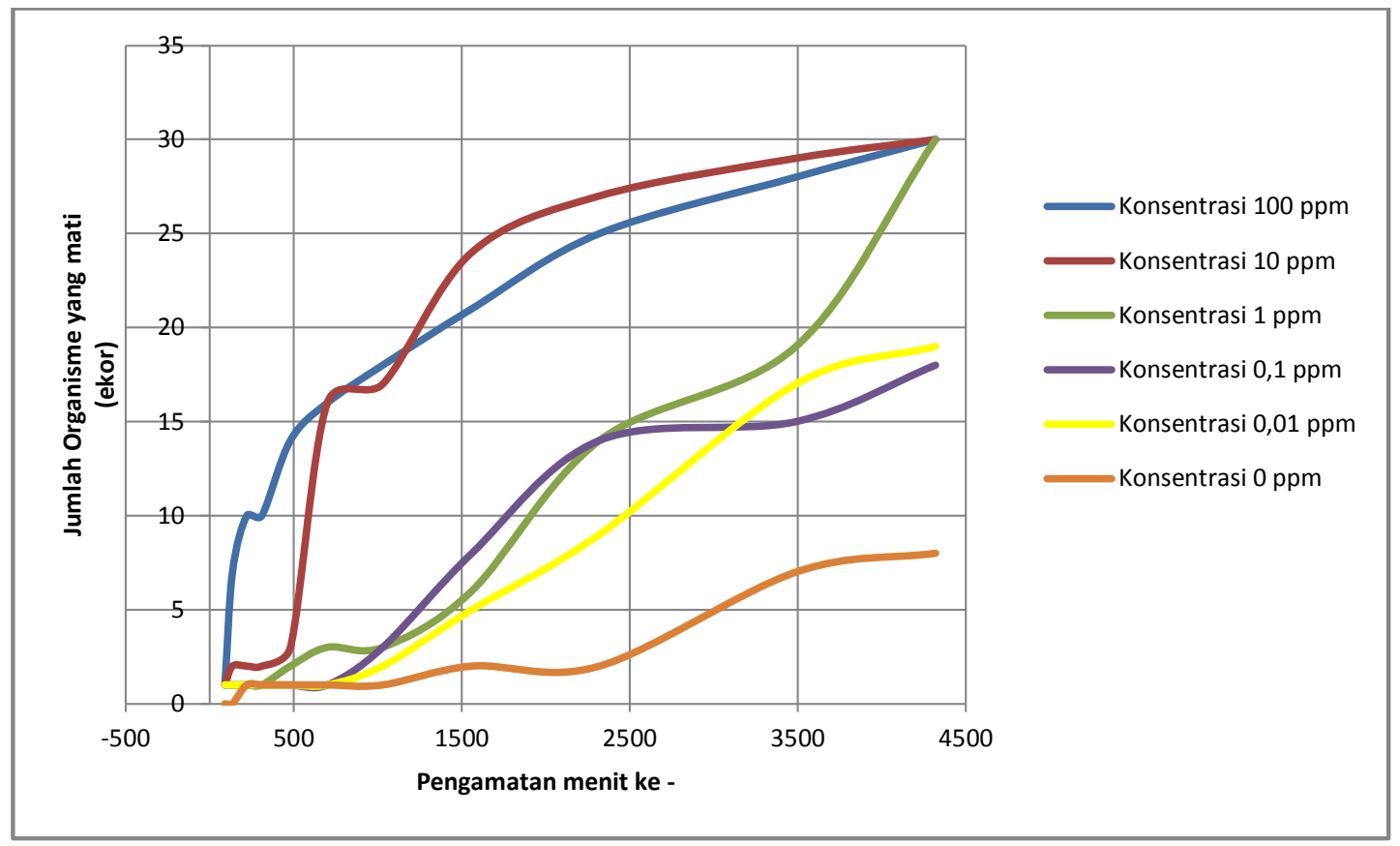

Gambar 1 Hubungan jumlah kematian organisme Chiromus sp dengan waktu pengamatan

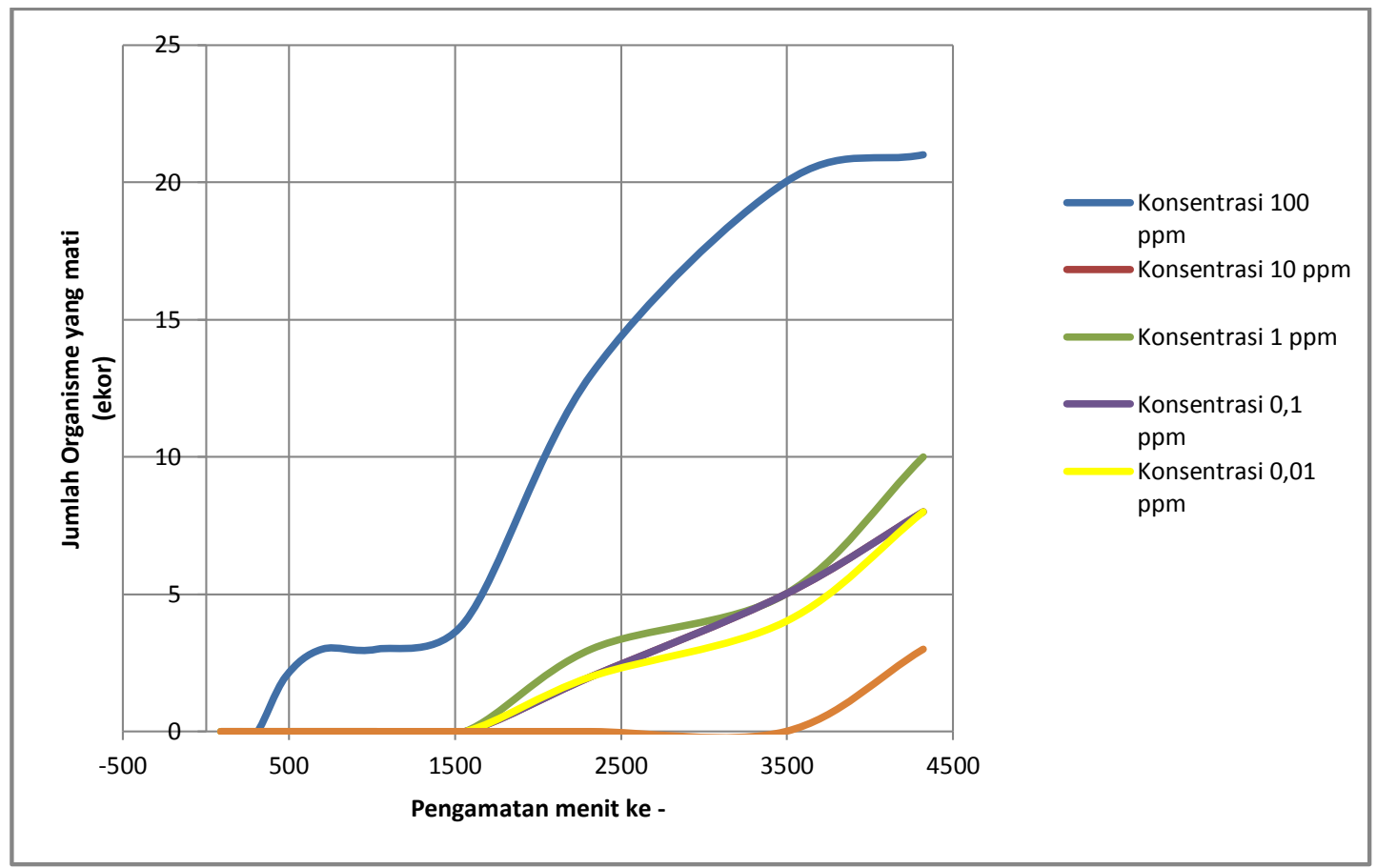

Gambar 2 Hubungan jumlah kematian organisme Daphnia carinata dengan waktu pengamatan 


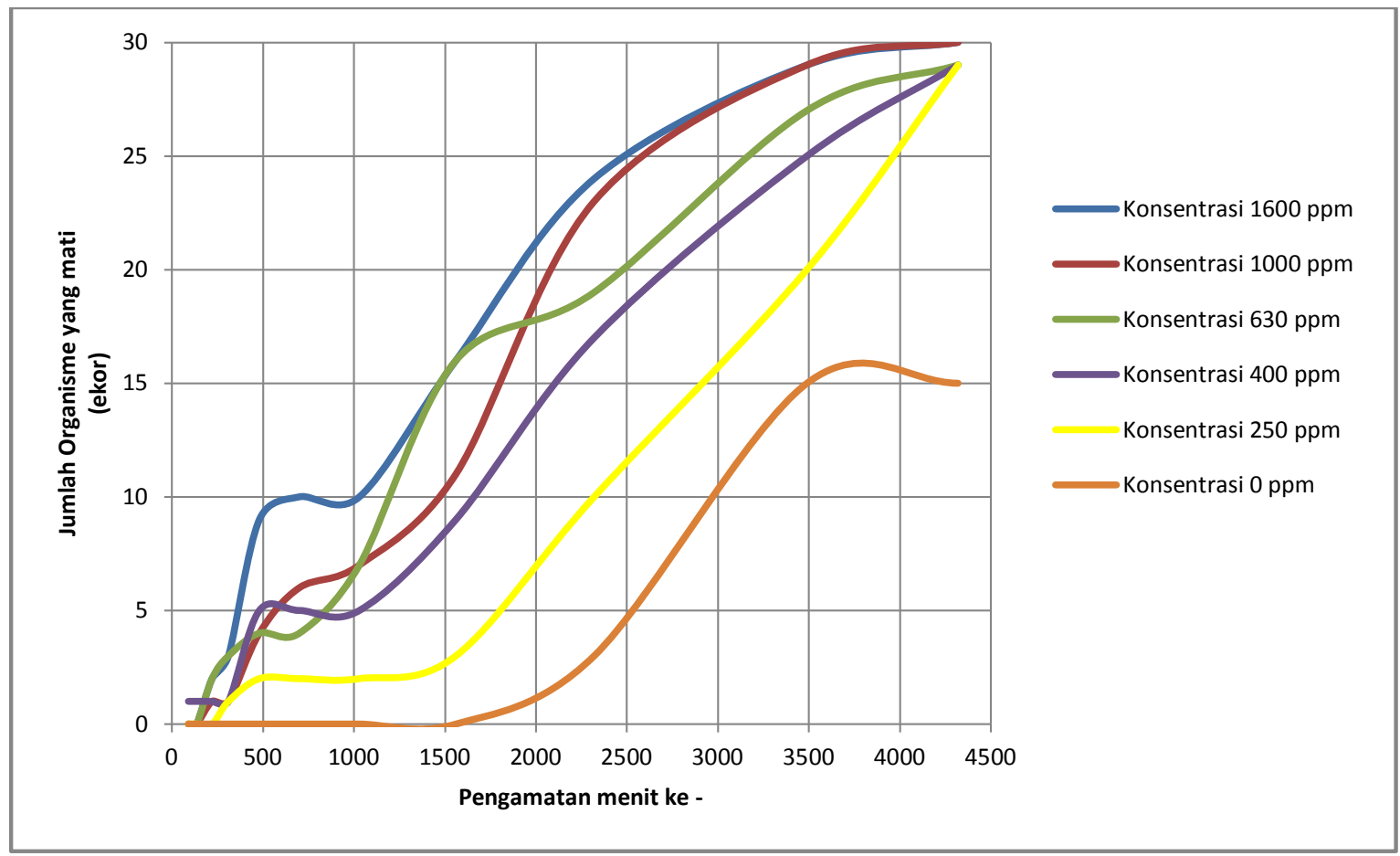

Gambar 3 Hubungan jumlah kematian organisme Culex sp dengan waktu pengamatan

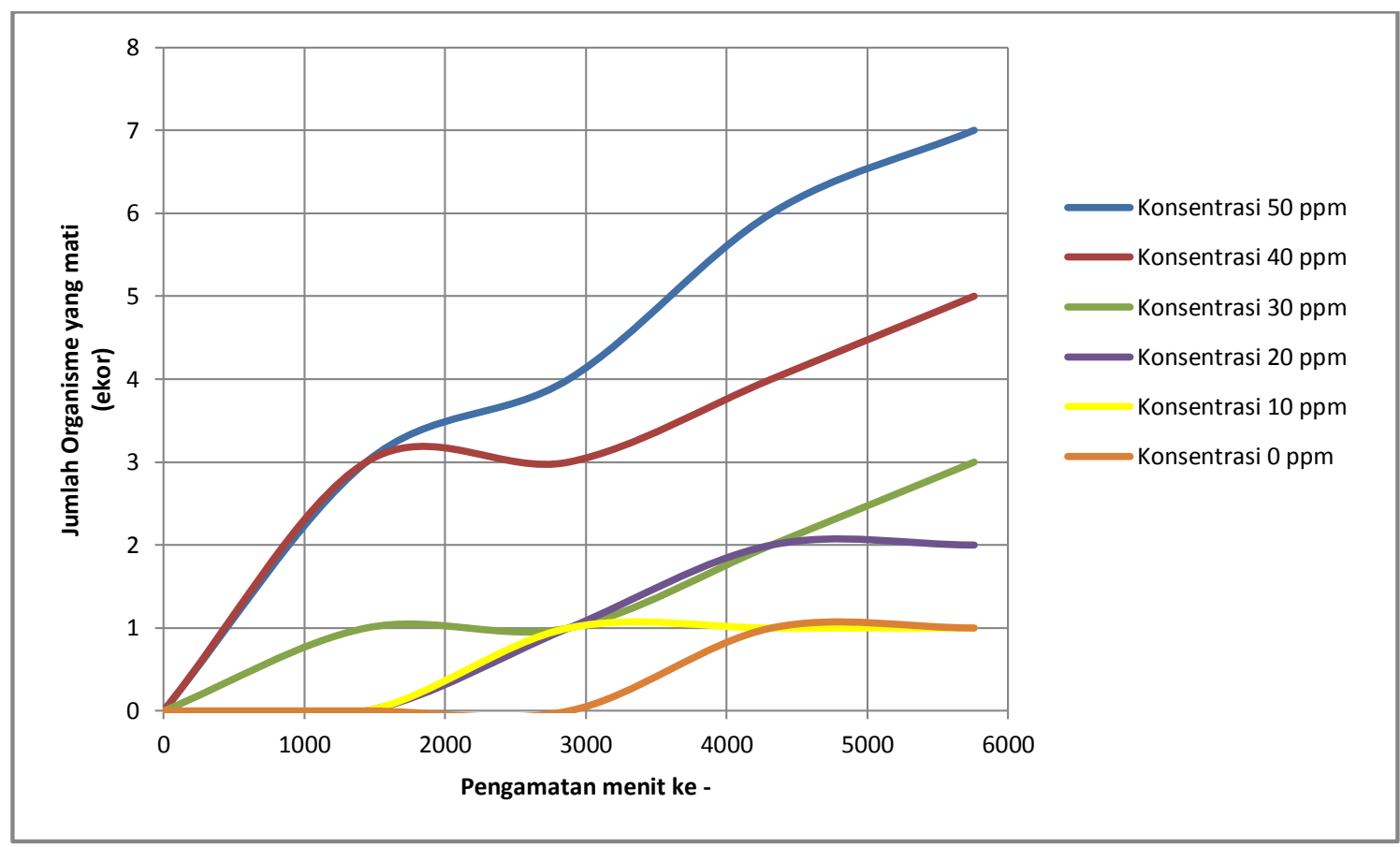

Gambar 4 Hubungan jumlah kematian organisme Cyprinus carpio L dengan waktu pengamatan akibat pemberian deterjen bubuk (rinso anti noda)

Kematian jumlah organisme Cyprinus carpio $L$ yang diamati dalam penelitian ini berasal dari tiga penelitian (Halang, 2004; Pratiwi dkk, 2015; Lubis dkk, 2014). Data hasil penelitian Halang, 2004 menggunakan konsentrasi deterjen (ppm) : 0; 10;
$20 ; 30 ; 40 ; 40 ; 50$, waktu pengamatan (menit): 0; $1440 ; 2880 ; 4320 ; 5760$, dengan jumlah organisme masing - masing konsentrasi sebanyak 10 ekor. Hubungan antara jumlah organisme yang mati 
dengan waktu pengamatan dapat dilihat pada Gambar 4.

Data hasil penelitian Pratiwi dkk, 2012 menggunakan konsentrasi air limbah (ppm) : 0; 0,$001 ; 0,002 ; 0,003 ; 0,004 ; 0,005 ; 0,006 ; 0,007$; 0,$008 ; 0,009 ; 0,01$, dengan waktu pengamatan dan jumlah organisme masing - masing konsentrasi sama dengan telah dilakukan Halang, 2004. Hubungan antara jumlah organisme yang mati dengan waktu pengamatan dapat dilihat pada Gambar 5.

Data hasil penelitian Lubis dkk, 2014 menggunakan konsentrasi air limbah (ppm) : 0;
17,$78 ; 31,62 ; 56,23 ; 100$, waktu pengamatan (menit): 360; 720; 1080; 2160; 3600; 4320; 5040; 5760 dengan jumlah organisme masing - masing konsentrasi sebanyak 30 ekor. Hubungan antara jumlah organisme yang mati dengan waktu pengamatan dapat dilihat pada Tabel 4.

Data hasil penelitian Hardini dkk, 2012 menggunakan konsentrasi air limbah (ppm) : 2,4; 5,$6 ; 7,5 ; 10 ; 13$, dengan waktu pengamatan dan jumlah organisme Orheochromis nilaticus masing masing konsentrasi sebanyak 30 ekor. Hubungan antara jumlah organisme yang mati dengan waktu pengamatan dapat dilihat pada Gambar 6.

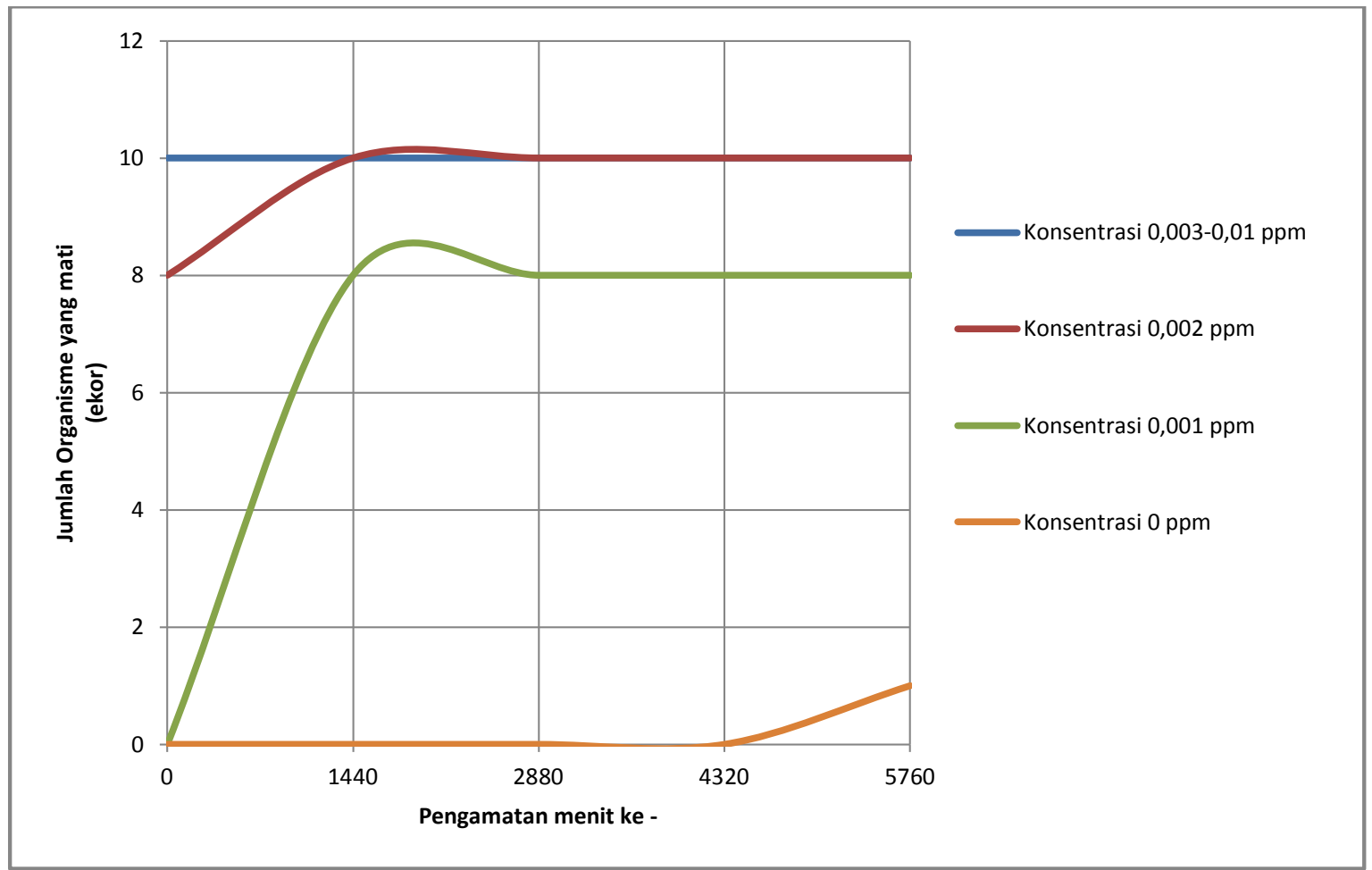

Gambar 5 Hubungan jumlah kematian organisme Cyprinus carpio $L$ dengan waktu pengamatan akibat pemberian air limbah laundry

Tabel 4 Hubungan jumlah kematian organisme Cyprinus carpio $L$ dengan waktu pengamatan akibat pemberian deterjen cair

\begin{tabular}{|c|c|c|c|c|c|c|c|c|c|c|c|}
\hline \multirow{2}{*}{$\begin{array}{l}\text { Konnsentrasi } \\
\text { Detergen (ppm) }\end{array}$} & \multirow{2}{*}{$\begin{array}{c}\text { Jumlah Organisme } \\
\text { (ekor) }\end{array}$} & \multicolumn{10}{|c|}{ Jumlah organisme yang mati pada masa inkubasi atau pengamatan menit ke- } \\
\hline & & 360 & 720 & 1080 & 1440 & 2160 & 2880 & 3600 & 4320 & 5040 & 5760 \\
\hline 100 & 30 & 30 & 30 & 30 & 30 & 30 & 30 & 30 & 30 & 30 & 30 \\
\hline 56,23 & 30 & 25 & 25 & 25 & 25 & 25 & 25 & 25 & 25 & 25 & 25 \\
\hline 31,62 & 30 & 0 & 0 & 0 & 0 & 0 & 0 & 1 & 2 & 4 & 5 \\
\hline 17,78 & 30 & 0 & 0 & 0 & 0 & 0 & 0 & 0 & 0 & 0 & 0 \\
\hline 0 & 30 & 0 & 0 & 0 & 0 & 0 & 0 & 0 & 0 & 0 & 0 \\
\hline
\end{tabular}




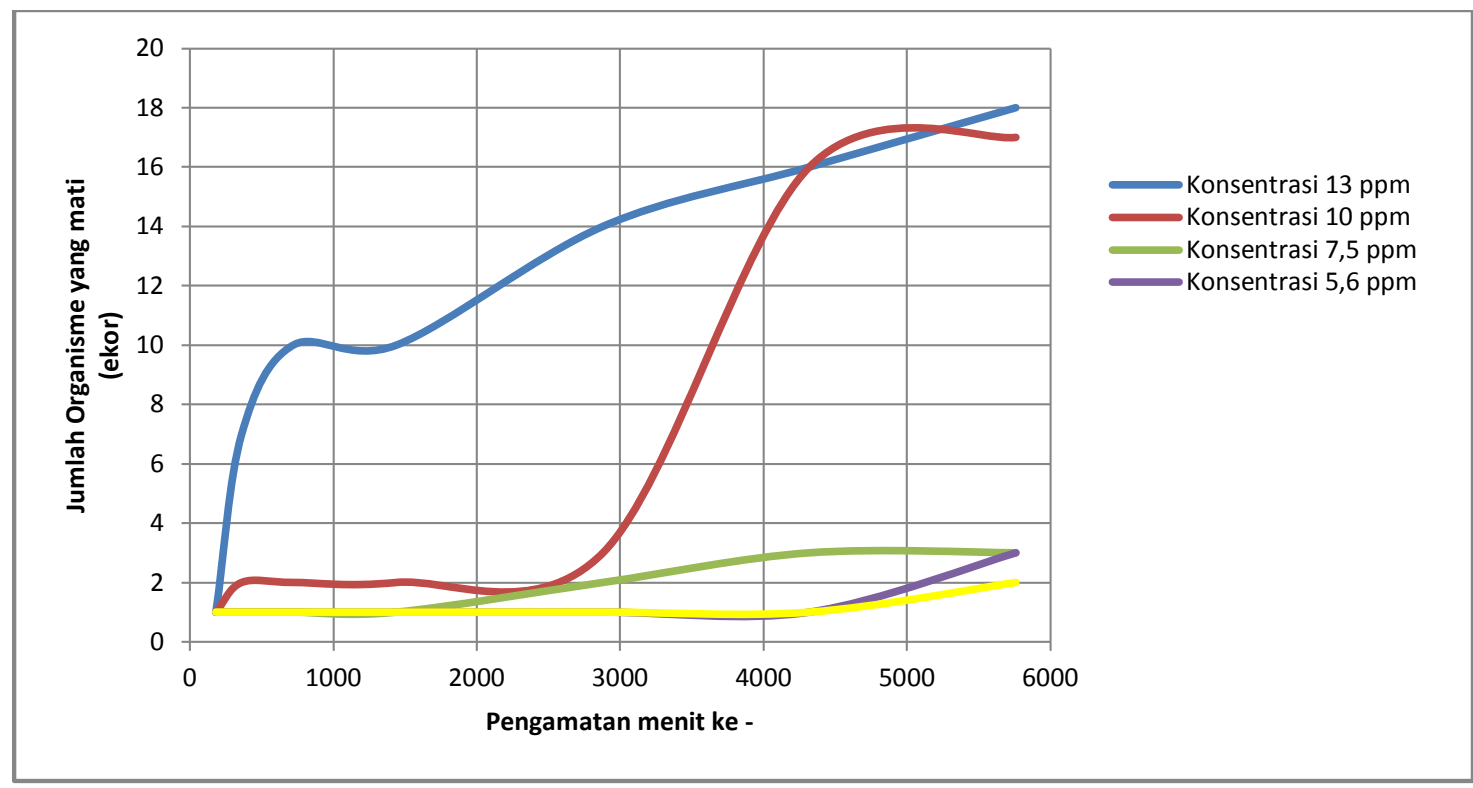

Gambar 6 Hubungan jumlah kematian organisme Orheochromis Nilaticus dengan waktu pengamatan

Hubungan antara kematian organisme dengan adanya limbah deterjen melalui persamaan matematis beserta koefisien korelasinya baik berupa hubungan jumlah kematian terhadap waktu untuk biota air Chiromus sp, Daphnia carinata, Culex sp, Cyprinus carpio $L$ dan Orheochromis nilaticus dapat dilihat pada Tabel 5 .

Model hubungan kematian organisme akibat limbah deterjen dibuat berdasarkan distribusi sebaran yang paling mendekati bentuk grafiknya. Tiga persamaan dibuat berdasarkan sebaran distribusi hubungan, yaitu persamaan linear, persamaan logaritma, dan polynomial orde 2.

Sistem coba - coba (try and eror) dilakukan dalam penelitian ini berdasarkan asumsi : hubungan waktu dan jumlah kematian mengikuti regresi liniear (persamaan linear), regresi suku banyak misalnya pangkatnya berderajat 2 (polynominal orde 2) dan regresi non linear misalnya persamaan logaritma. Persamaan polynomial orde 2 sendiri merupakan persamaan matematika suku banyak, melibatkan perkalian pangkat dari variabel bebasnya dengan koefisien, dimana pangkat pangkat tertinggi ada pada derajat dua. Persamaan polynominal orde 2 lebih dikenal dengan nama persamaan kuadrat.

Ketiga persamaan matematis tersebut, menunjukkan bahwa hubungan jumlah kematian organisme Chironomus sp dengan waktu pengamatan dengan korelasi yang sangat kuat ditunjukkan dengan persamaan linear dan polynomial orde 2 . Tetapi, berdasarkan besarnya nilai koefisien korelasi, maka persamaan yang paling mendekati hubungan tersebut, persamaan polynomial orde 2 lebih tepat digunakan dalam menyatakan hubungan kematian Chironomus $s p$ terhadap waktu pengamatan akibat pemberian konsentrasi limbah deterjen. Korelasi sangat kuat pada persamaan polynominal orde 2 juga ditunjukan untuk organisme Daphnia carinata, dan Culex sp.

Korelasi yang sangat kuat pada setiap konsentrasi detergen secara terus menerus (simultan) menunjukkan bahwa persamaan polynominal orde 2 dapat dipakai untuk dijadikan model matematis hubungan jumlah kematian ketiga organisme dengan waktu pengamatan sebagai waktu kontak zat pencemar deterjen dengan organisme. Hal tersebut juga bermakna bahwa kematian organisme (Chironomus, Daphnia carinata, dan Culex $s p$ ) akibat konsentrasi deterjen akan bertambah banyak sejalan dengan kuadrat pangkat waktu pengamatan. Kematian organisme tersebut disebabkan meningkatnya kadar detergen sehingga terjadi kekurangan oksigen. Dampak selanjutannya terjadi gangguan fisiologis pada organisme tersebut sehingga terjadi kerusakan ingsang, hati, jantung dan organ vital organisme lainnya.

Hubungan jumlah kematian organisme Cyprinuscarpio $L$ dengan waktu pengamatan dibedakan menjadi dua yaitu grafik (Gambar 4 dan 5) serta Tabel 4, sehingga persamaan matematiknya dipisah. Hubungan jumlah kematian organisme Cyprinuscarpio $L$ dengan waktu pengamatan yang pertama dilakukan untuk jenis air limbah deterjen bubuk (rinso anti noda), yang kedua menggunakan air limbah laundry dan yang ketiga menggunakan air limbah deterjen cair. 
Tabel 5 Hubungan kematian biota terhadap konsentrasi deterjen dalam persamaan matematis

\begin{tabular}{|c|c|c|c|c|c|c|c|c|c|}
\hline \multirow{2}{*}{ Jenis Biota Air } & \multirow{2}{*}{ Variabel } & \multirow{2}{*}{$\begin{array}{c}\text { Jumlah } \\
\text { Biota air }\end{array}$} & \multirow{2}{*}{\begin{tabular}{|c|} 
Konsentrasi \\
(ppm)
\end{tabular}} & \multicolumn{2}{|c|}{ Persamaan Linear } & \multicolumn{2}{|c|}{ Persamaan Logaritma } & \multicolumn{2}{|c|}{ Persamaan Polynomial orde 2} \\
\hline & & & & y & $\mathrm{R}^{2}$ & y & $\mathrm{R}^{2}$ & y & $\mathrm{R}^{2}$ \\
\hline \multirow[t]{6}{*}{ Chironomus sp } & \multirow{6}{*}{\begin{tabular}{|ll}
$\mathrm{y}:$ & $\begin{array}{l}\text { Jumlah kematian } \\
\text { organisme (ekor) }\end{array}$ \\
$\mathrm{x}:$ & $\begin{array}{l}\text { Waktu pengamatan } \\
\text { (menit) }\end{array}$
\end{tabular}} & 30 & 0 & $0,0018 x-0,1885$ & 0,9064 & $1,6506 \ln (x)-8,5961$ & 0,6355 & $4.10^{-7} x^{2}+0,0003 x+0,4546$ & 0,9497 \\
\hline & & 30 & 0,01 & $0,0046 x-0,8442$ & 0,9659 & $4,2289 \ln (x)-22,341$ & 0,6676 & $5.10^{-7} x^{2}+0,0026 x+0,0339$ & 0,9788 \\
\hline & & 30 & 0,1 & $0,0045 x-0,1734$ & 0,9443 & $4,4546 \ln (x)-23,269$ & 0,7547 & $-4.10^{-7} x^{2}+0,0061 x-0,8641$ & 0,9524 \\
\hline & & 30 & 1 & $0,0065 x-1,276$ & 0,9612 & $6,0059 \ln (x)-31,854$ & 0,6716 & $1.10^{-6} x^{2}+0,0025 x+0,4542$ & 0,9862 \\
\hline & & 30 & 10 & $0,0075 x+3,887$ & 0,8036 & $8,8591 \ln (x)-43,939$ & 0,9079 & $-3.10^{-6} x^{2}+0,0199 x-1,5167$ & 0,9550 \\
\hline & & 30 & 100 & $0,0057 x+8,7144$ & 0,8369 & $6,9030 \ln (x)-28,711$ & 0,9855 & $-2.10^{-6} x^{2}+0,0132 x+5,4546$ & 0,9354 \\
\hline \multirow[t]{6}{*}{ Daphnia Carinata } & \multirow{6}{*}{$\begin{array}{l}\mathrm{y}: \begin{array}{l}\text { Jumlah kematian } \\
\text { organisme (ekor) }\end{array} \\
\mathrm{x}: \begin{array}{l}\text { Waktu pengamatan } \\
\text { (menit) }\end{array}\end{array}$} & 30 & 0 & $0,0004 x-0,2936$ & 0,4657 & $0,3216 \ln (x)-1,827$ & 0,2171 & $-3.10^{-7} x^{2}-0,0009 x-0,2821$ & 0,7776 \\
\hline & & 30 & 0,01 & $0,0016 x-0,9076$ & 0,8533 & $1,3786 \ln (x)-7,7291$ & 0,4933 & $6.10^{-7} x^{2}-0,0008 x+0,1672$ & 0,9877 \\
\hline & & 30 & 0,1 & $0,0017 x-0,953$ & 0,8789 & $1,4733 \ln (x)-8,257$ & 0,5140 & $6.10^{-7} x^{2}-0,0007 x+0,0926$ & 0,9949 \\
\hline & & 30 & 1 & $0,0021 x-1,1202$ & 0,8635 & $1,7587 \ln (x)-9,8477$ & 0,5082 & $7.10^{-7} x^{2}-0,0008 x-0,1373$ & 0,9799 \\
\hline & & 30 & 10 & $0,0017 x-0,953$ & 0,8789 & $1,4733 \ln (x)-8,257$ & 0,5140 & $6.10^{-7} x^{2}-0,0007 x+0,0926$ & 0,9949 \\
\hline & & 30 & 100 & $0,0055 x-1,2748$ & 0,9643 & $5,2943 \ln (x)-28,57$ & 0,7384 & $9.10^{-8} x^{2}+0,0051 x-1,1189$ & 0,9646 \\
\hline \multirow[t]{6}{*}{ Culex sp } & \multirow{6}{*}{$\begin{array}{l}\mathrm{y}: \begin{array}{l}\text { Jumlah kematian } \\
\text { organisme (ekor) } \\
\mathrm{x}:\end{array} \\
\begin{array}{l}\text { Waktu pengamatan } \\
\text { (menit) }\end{array}\end{array}$} & 30 & 0 & $0,0038 x-2,0637$ & 0,8462 & $3,3423 \ln (x)-18,172$ & 0,5016 & $1.10^{-6} x^{2}-0,0006 x-0,1385$ & 0,9254 \\
\hline & & 30 & 250 & $0,0064 x-2,3051$ & 0,9397 & $5,8197 \ln (x)-31,729$ & 0,6255 & $1.10^{-6} x^{2}+0,0006 x+0,2478$ & 0,9937 \\
\hline & & 30 & 400 & $0,0069 x-0,2196$ & 0,9861 & $6,8117 \ln (x)-35,479$ & 0,7783 & $5.10^{-8} x^{2}+0,0067 x-0,1229$ & 0,9862 \\
\hline & & 30 & 630 & $0,0073 x-0,3629$ & 0,9684 & $7,5996 \ln (x)-39,533$ & 0,8546 & $-9.10^{-7} x^{2}+0,011 x-1,2512$ & 0,9857 \\
\hline & & 30 & 1000 & $0,0079 x-0,3049$ & 0,9651 & $8,1019 \ln (x)-42,722$ & 0,8330 & $-9.10^{-7} x^{2}+0,0116 x-1,9228$ & 0,9903 \\
\hline & & 30 & 1600 & $0,0075 x+2,1556$ & 0,9315 & $7,5996 \ln (x)-39,533$ & 0,9234 & $-2.10^{-6} x^{2}+0,0141 x-0,7242$ & 0,9845 \\
\hline \multirow[t]{6}{*}{ Cyprinuscarpio L } & \multirow{6}{*}{$\begin{array}{l}\mathrm{y}: \begin{array}{l}\text { Jumlah kematian } \\
\text { organisme (ekor) }\end{array} \\
\mathrm{x}: \begin{array}{l}\text { Waktu pengamatan } \\
\text { (menit) }\end{array}\end{array}$} & 10 & 0 & $0,0002 x-0,2$ & 0,7500 & - & - & $3.10^{-8} x^{2}+1.10^{-5} x-0,0571$ & 0,8095 \\
\hline & & 10 & 10 & $0,0002 x$ & 0,7500 & - & - & $-3.10^{-8} x^{2}+0,0004 x-0,1429$ & 0,8095 \\
\hline & & 10 & 20 & $0,0004 x-0,2$ & 0,9000 & - & - & $4.10^{-22} x^{2}+0,0004 x-0,2$ & 0,9000 \\
\hline & & 10 & 30 & $0,0005 x$ & 0,9423 & - & $\therefore$ & $3.10^{-8} x^{2}+0,0003 x+0,1429$ & 0,9560 \\
\hline & & 10 & 40 & $0,0008 x+0,8$ & 0,8643 & - & - & $-1.10^{-7} x^{2}+0,0014 x+0,3714$ & 0,9102 \\
\hline & & 10 & 50 & $0,0012 x+0,6$ & 0,9633 & - & - & $-1.10^{-7} x^{2}+0,0018 x+0,1714$ & 0,9848 \\
\hline \multirow[t]{4}{*}{ Cyprinuscarpio L } & \multirow{4}{*}{$\begin{array}{l}\text { Jumlah kematian } \\
\text { organisme (ekor) } \\
\text { Waktu pengamatan } \\
\text { (menit) }\end{array}$} & 10 & 0 & $0,0001 x-0,2$ & 0,5000 & - & - & $7.10^{-8} x^{2}-0,0003 x+0,0857$ & 0,8571 \\
\hline & & 10 & 0,001 & $0,0011 x+3,2$ & 0,5000 & - & - & $-6.10^{-7} x^{2}+0,0043 x+0,9143$ & 0,8571 \\
\hline & & 10 & 0,002 & $0,0003 x+8,8$ & 0,5000 & - & - & $1.10^{-7} x^{2}+0,0011 x+8,2286$ & 0,8571 \\
\hline & & 10 & $0,003-0,01$ & - & - & - & - & - & - \\
\hline \multirow[t]{5}{*}{ Cyprinuscarpio $L$} & \multirow{5}{*}{$\begin{array}{l}\mathrm{y}: \begin{array}{l}\text { Jumlah kematian } \\
\text { organisme (ekor) }\end{array} \\
\mathrm{x}: \begin{array}{l}\text { Waktu pengamatan } \\
\text { (menit) }\end{array}\end{array}$} & 30 & 0 & - & - & - & - & - & - \\
\hline & & 30 & 17,78 & - & - & - & - & - & \\
\hline & & 30 & 31,62 & $0,0009 x-1,2110$ & 0,7911 & $1,4616 \ln (x)-9,9242$ & 0,5085 & $3.10^{-7} x^{2}-0,0009 x+0,4958$ & 0,9831 \\
\hline & & 30 & 17,78 & - & - & - & - & - & - \\
\hline & & 30 & 100 & - & - & - & - & - & - \\
\hline \multirow{5}{*}{$\begin{array}{l}\text { Orheochromis } \\
\text { Niloticus }\end{array}$} & \multirow{5}{*}{$\begin{array}{l}\mathrm{y}: \begin{array}{l}\text { Jumlah kematian } \\
\text { organisme (ekor) }\end{array} \\
\mathrm{x}: \begin{array}{l}\text { Waktu pengamatan } \\
\text { (menit) }\end{array}\end{array}$} & 30 & 2,4 & $0,0001 x+0,8599$ & 0,5198 & $0,1497 \ln (x)+0,0753$ & 0,2665 & $7.10^{-8} x^{2}-0,0003 x+1,1309$ & 0,8729 \\
\hline & & 30 & 5,6 & $0,0003 x+0,7198$ & 0,5198 & $0,2994 \ln (x)-0,8493$ & 0,2665 & $1.10^{-7} x^{2}-0,0006 x+1,2618$ & 0,8729 \\
\hline & & 30 & 7,5 & $0,0004 x+0,9293$ & 0,9293 & $0,624 \ln (x)-2,7362$ & 0,7315 & $6.10^{-9} x^{2}+0,0005 x+0,7408$ & 0,9297 \\
\hline & & 30 & 10 & $0,003 x-0,8505$ & 0,8505 & $4,2175 \ln (x)-23,938$ & 0,5990 & $4.10^{-7} x^{2}+0,0005 x+0,9774$ & 0,8870 \\
\hline & & 30 & 13 & $0,0024 x+5,4442$ & 0,8119 & $4,3311 \ln (x)-20,034$ & 0,9524 & $-5.10^{-7} x^{2}+0,0051 x+3,6815$ & 0,8756 \\
\hline
\end{tabular}

Pada jenis air limbah pertama. korelasi yang sangat kuat ditunjukkan pada persamaaan polynomial orde 2, dengan koefisien determinasi terletak antara $\mathrm{R}^{2}=0,8095-0,9848$.

Jenis air limbah kedua, pada konsentrasi $\leq$ 0,002 ppm korelasi sangat kuat dinyatakan dalam persamaan polynominal orde 2. Sedangkan, konsentrasi 0,003 keatas langsung terjadi kematian terhadap organisme yang diuji yaitu sebanyak 10 ekor, sehingga untuk konsentrasi $\geq$ 0,003 ppm persamaannya adalah $\mathrm{y}=\mathrm{c}$, dimana $\mathrm{c}$ adalah jumlah individu uji.

Pada jenis air limbah ketiga, pada konsentrasi 31,62 ppm dapat dinyatakan tiga persamaan yaitu linear, logaritma dan polynominal orde dua. Diluar konsentrasi tersebut, persamaan matematisnya merupakan konstanta yaitu untuk konsentrasi 0 dan 17,78 ppm tidak terjadi kematian $(\mathrm{y}=0)$, sedangkan untuk konsentrasi 56,23 terjadi kematian sebanyak 25 ekor $(y=25)$ dan konsentrasi 100 semua ikan uji mati yaitu sebanyak 30 ekor $(y=30)$. Pada konsentrasi 31,62 ppm tersebut, menununjukkan bahwa persamaan polynominal orde dua dapat digunakan untuk menyatakan hubungan kematian terhadap waktu pengamatan.

Hubungan jumlah kematian organisme Orheochromis niloticus dengan waktu pengamatan 
dalam persamaan matematis dengan korelasi yang sangat kuat ditunjukkan dan persamaan polynomial orde 2 .

Biota air yang telah dianalisis, baik Chiromus $s p$, Daphnia carinata, Culex sp, Cyprinus carpio L dan Orheochromis nilaticus, menunjukkan suatu kesamaan yaitu dari ketiga persamaan (linear. Logaritma dan polynominal orde dua), maka persamaan polynominal orde dua dapat menyatakan hubungan antara banyaknya kematian biota air dengan waktu pengamatan. Persamaan tersebut dapat digunakan karena korelasinya sangat tinggi berkisar dari $\mathrm{R}^{2}=0,7776-0,9949$ dengan kondisi konsentrasi masih bisa ditoleransi oleh biota air. Pada kondisi konsentrasi yang paling rendah, tidak terdapat kematian biota air, hal ini ditunjukkan oleh organisme Cyprinuscarpio $L$ pada konsentrasi limbah cair deterjen $0-17,78$ ppm. Konsentrasi paling rendah pun masih terdapat kematian biota yaitu Chiromus $s p$ pada konsentrasi $0,01 \mathrm{ppm}$ telah terjadi kematian pada menit ke 90 (3,33\%) , dan Daphnia carinata pada konsentrasi 0,01 -1 ppm pada menit ke 1560 $(6,67 \%$ - 10). Cyprinus carpio $L$ sendiri pada deterjen bubuk rinso anti noda pada 10 ppm terjadi kematian pada menit ke - 2880 (10\%). Sedangkan, Cyprinus carpio $L$ pada limbah cair laundry pada konsentrasi $0.001 \mathrm{ppm}$ terjadi kematian pada menit ke - 1440 (80\%).

Penelitian diatas menunjukkan bahwa pada konsentrasi 0,01 ppm (paling rendah) pun masih terjadi kematian seiring bertambahnya waktu. Hal tersebut terjadi karena penggunaan deterjen yang berbeda jenis, yaitu deterjen bubuk rinso pada Chiromus sp dan Daphnia carinata (Garno, 2000), deterjen bubuk rinso anti noda pada Cyprinus carpio L (Halang, 2004), limbah laundry (Pratiwi $\mathrm{dkk}, 2012$ ). Penggunaan deterjen bubuk dan jenis deterjen laundry biasanya menimbulkan busa dalam permukaan air walaupun dalam konsentrasi rendah. Berbeda dengan penggunaan deterjen cair dengan organisme uji Cyprinus carpio L (Lubis dkk, 2014) pada konsentrasi rendah tidak menimbulkan menimbulkan buih/busa setelah proses pencucian. Keberadaan busa - busa dipermukaan air diduga menyebabkan menurunnya oksigen terlarut dalam air sehingga oksigen tidak bisa bertambah karena hubungan dengan udara bebas tertutup, dengan bertambahnya waktu, organisme di badan air akan kekurangan oksigen dan lama kelamaan akan mati (Garno, 2000). Penelitian lain menunjukkan peningkatan konsentrasi deterjen bubuk telah menurunkan kadar oksigen terlarut dalam air, sehingga biota kekurangan oksigen dalam air (Hermawati dkk, 2005).

Penggunaan deterjen bubuk rinso, deterjen bubuk rinso anti noda dan deterjen laundry biasanya menggunakan deterjen yang tergolong keras berbeda dengan deterjen cair yang menggunakan deterjen tipe "soft". Deterjen tipe ini biasanya mengandung surfaktan jenis anionic seperti ABS (alkyl benzene sulphonate), yang bersifat nonbiodegradable (Halang, 2004 ; Pratiwi dkk, 2012). Kematian biota dalam limbah cair laundry lebih cepat dari limbah cair deterjen di duga karena deterjen yang digunakan beragam misalnya anti noda, anti bakteri, anti luntur, dll, sehingga surfaktan yang digunakan dalam air limbah menjadi lebih besar. Selain itu jumlah organisme yang di uji (10 ekor) lebih sedikit jika dibandingkan dengan organisme uji pada deterjen cair (30 ekor).

Pada konsentrasi yang tinggi yaitu 56,23 ppm dengan penggunaan deterjen cair (Lubis dkk, 2014), terjadi kematian sebanyak 25 ekor $(\mathrm{y}=25)$, prosentase Cyprinus carpio $L$ yang mati sebesar 83,3\%. Penelitian ini menunjukkan bahwa pada penggunaan konsentrasi deterjen cair yang tinggi, hubungan antara banyaknya kematian biota air dengan waktu pengamatan dapat dinyatakan dengan konstanta tertentu $(\mathrm{y}=>80 \%)$.

Pada konsentrasi yang paling tinggi yaitu 56,23 ppm dengan penggunaan deterjen cair (Lubis dkk, 2014), terjadi kematian pada semua organisme uji ( $\mathrm{y}=$ 30). Kematian semua organisme uji, terjadi juga pada penggunaan air limbah laundry $\geq 0,003 \mathrm{ppm}(\mathrm{y}=10)$. Penelitian ini menunjukkan bahwa pada penggunaan konsentrasi deterjen cair yang paling tinggi, hubungan antara banyaknya kematian biota air dengan waktu pengamatan dapat dinyatakan dengan konstanta tertentu $(\mathrm{y}=$ jumlah organisme uji).

Pada dasarnya kematian biota air, selain dipengaruhi oleh jenis surfaktan yang digunakan dan konsentrasi surfaktan, jenis organisme biota air juga berpengaruh. Culex $s p$ memiliki daya tahan yang lebih baik daripada Daphnia carinata dan Chironomus sp, dalam waktu 38 jam 50\% larva Culex sp masih bertahan dengan rinso terlarut 400ppm; Daphnia carinata 100 ppm dan Chironomus sp hanya dalam media rinso terlarut 0,1 ppm (Garno, 2000).

Kematian biota air akibat adanya deterjen pada badan air di duga disebabkan oleh kerusakan organ vital biota air dan menurunnya kualitas air. Surfaktan dalam deterjen dimungkinkan berpengaruh terhadap kerusakan organ vital tersebut antara lain ingsang, jantung, sel membran, menyerang protein serta mempengaruhi sel pada prose fisiologis dan biokimia. Hal ini dikuatkan oleh penelitian sebelumnya yaitu keberadaan deterjen dalam badan air dapat merusak ingsang dan organ pernafasan ikan (Garno, 2000; Aini 2013), kematian organisme air merupakan kombinasi sifat racun deterjen dan turunnya kualitas air (Garno, 2000), zat toksik (deterjen) 
dapat menghambat kerja enzim dalam tubuh ikan mas (Mautidina 2000; Halang, 2004)

Dugaan menurunnya kualitas air akibat adanya peningkatan deterjen di badan air di dukung pula oleh penelitian - penelitian lainnya (Hermawati dkk, 2005; Lubis dkk, 2014). Peningkatan konsentasi deterjen (Tabel 6) telah menaikan $\mathrm{pH}$, menurunkan oksigen dan menaikkan suhu (Hermawati dkk, 2005). Menurut Lubis, 2014 konsentrasi deterjen yang tinggi dapat menurunkan oksigen (DO) dan menaikkan suhu, di dukung oleh penelitiannya yaitu : hasil pengukuran kualitas air pada uji pendahuluan deterjen cair menunjukkan parameter DO terendah pada konsentrasi tertinggi yaitu 1000 ppm dengan kisaran DO 2,6-3,3 mg/L, pH tidak mengalami fluktuasi yang begitu besar serta pada Konsentrasi tertinggi 1000 ppm suhu meningkat yaitu berkisar 30-31,5 oC.

Tabel 6 Parameter kualitas air terhadap perubahan konsentrasi deterjen

\begin{tabular}{lccccc}
\hline \multirow{2}{*}{ Parameter } & \multicolumn{6}{c}{ Konsentrasi detergen (\%) } \\
\cline { 2 - 6 } & 0 & 20 & 40 & 60 & 100 \\
\hline $\mathrm{pH}$ & 7,85 & 9,31 & 9,75 & 9,94 & 12,00 \\
$\mathrm{DO}(\mathrm{mg} / \mathrm{L})$ & 8,07 & 6,35 & 4,00 & 2,50 & 1,03 \\
Suhu $\left({ }^{\circ} \mathrm{C}\right)$ & 30,6 & 31,6 & 31,7 & 32,4 & 33,0 \\
\hline \multicolumn{5}{l}{ Sumber : Hermawati dkk, 2005}
\end{tabular}

Kenaikan suhu air akan menurunkan oksigen terlarut dalam air, meningkatnya kecepatan reaksi kimia sehingga terganggunya biota air. Naiknya suhu air yg relatif tinggi ditandai dengan munculnya biota ke permukaan untuk mencari oksigen, apabila suhu tidak kembali normal, lama kelamaan biota air akan mati (Nugroho, 2006).

Nilai pH ideal bagi biota air terletak antara 7 8,5 (Aini 2013). Kondisi perairan yang sangat asam maupun sangat basa akan membahayakan kelangsungan hidup organisme karena akan menyebabkan terjadinya gangguan metabolisme dan respirasi (Barus, 2004). Konsentrasi paling tinggi deterjen di badan air (Tabel 6) menyebabkan kondisi perairan menjadi basa $(\mathrm{pH}=12)$ diduga menyebabkan gangguan tersebut, sehingga lama kelamaan organisme air akan mengalami kematian.

Uji biologis terhadap biota air, salah satunya uji kematian (mortalitas) merupakan salah satu uji untuk melihat pengaruh deterjen terhadap lingkungan sumber daya air secara tidak langsung, karena biota air ini membentuk ekosistem tersendiri dalam badan air. Kematian biota air akibat konsentrasi deterjen menjadi suatu warning indikator bagi pengelolaan sumber daya air, yaitu ketika limbah cair deterjen masuk ke badan air secara berlebih akan mengganggu keseimbangan lingkungan sumber daya air. Perubahan kualitas air sebagai petunjuk kematian organisme, diduga merupakan salah satu indikator bahwa air dengan kontaminasi deterjen yang tinggi tidak layak untuk sumber pemanfaatan/peruntukkan tertentu.

Konsentrasi deterjen yang sangat tinggi, membahayakan biota air tempat habitatnya. Penggunaan deterjen yang ramah lingkungan, serta pengolahan limbah cair deterjen sebelum masuk ke badan air diharapkan bisa lebih menyelamatkan biota air, sehingga ekosistem tetap terjaga.

\section{Upaya Pengendalian Pencemaran Deterjen Sebelumnya}

Pengolahan limbah cair deterjen sebagai upaya perbaikan atau penanggulangan dapat dilakukan dengan beberapa cara diantaranya : fitoremediasi, pengolahan kimia, dan proses filter menggunakan beberapa media.

Upaya penanggulangan atau perbaikan melalui pengolahan limbah cair ini sejalan dengan penelitian lainnya sebelumnya. Penelitian tersebut yaitu : fitoremediasi menggunakan kayu apu dan genjer(Hermawati dkk, 2005), pengolahan kimia melalui penggunaan tawas dan karbon aktif (Pratiwi dkk, 2012), proses filter melalui aerasi kontak menggunakan media kayu arang (Said dan Marsidi, 2004) dan filter keramik berbahan campuran tanah liat dan zeolit (Nasir dan Budi, 2011).

Tabel 7 Perbandingan Efisiensi Parameter Kualitas Air tanpa tanaman dan pengolahan melalui fitroremediasi

\begin{tabular}{|c|c|c|c|c|c|c|c|c|c|c|}
\hline \multirow{2}{*}{$\begin{array}{l}\text { Parameter } \\
\text { Kualitas Air }\end{array}$} & \multirow{2}{*}{$\begin{array}{l}\text { Konsentrasi } \\
\text { Detergen (\%) }\end{array}$} & \multicolumn{3}{|c|}{ Tanpa Tanaman } & \multicolumn{3}{|c|}{ Kayu Apu (Pistia stratiotes L.) } & \multicolumn{3}{|c|}{ Genjer (Limnochoris flava $L$ ) } \\
\hline & & Sebelum & Setelah & Efisiensi (\%) & Sebelum & Setelah & Efisiensi (\%) & Sebelum & Setelah & Efisiensi (\%) \\
\hline \multirow{2}{*}{ Suhu $\left({ }^{\circ} \mathrm{C}\right)$} & 20 & 31.60 & 26.80 & 15.19 & 31.60 & 27.10 & 14.24 & 31.60 & 26.90 & 14.87 \\
\hline & 60 & 32.40 & 27.70 & 14.51 & 32.40 & 26.90 & 16.98 & 32.40 & 27.30 & 15.74 \\
\hline \multirow{3}{*}{$\begin{array}{l}\text { Sulfat } \\
\text { (mg/L) }\end{array}$} & 0 & 0.13 & 0.12 & 7.69 & 0.13 & 0.07 & 49.23 & 0.13 & 0.06 & 53.85 \\
\hline & 20 & 1.50 & 1.42 & 5.33 & 1.50 & 1.30 & 13.40 & 1.50 & 1.31 & 12.53 \\
\hline & 40 & 2.30 & 1.56 & 32.35 & 2.30 & 1.42 & 38.26 & 2.30 & 1.52 & 34.09 \\
\hline \multirow{3}{*}{$\begin{array}{l}\text { Fosfat } \\
\text { (mg/L) }\end{array}$} & 20 & 2.00 & 1.46 & 27.20 & 2.00 & 1.16 & 41.90 & 2.00 & 1.42 & 28.85 \\
\hline & 40 & 2.00 & 1.64 & 17.80 & 2.00 & 1.65 & 17.55 & 2.00 & 1.46 & 27.20 \\
\hline & 60 & 2.90 & 2.54 & 12.34 & 2.90 & 2.12 & 26.86 & 2.90 & 1.98 & 31.83 \\
\hline
\end{tabular}

Catatan : Efisiensi dihitung berdasarkan sumber data Hermawati dkk, 2005 
Pengolahan limbah cair deterjen melalui fitroremediasi, menunjukkan hasil bahwa terdapat kenaikan efisiensi pengolahan setelah 14 hari jika dibandingkan dengan tanpa tanaman (Tabel 7). Tanaman kayu apu dapat menurunkan suhu sebesar $16,98 \%$, sulfat sebesar $42,28 \%$ dan fosfat sebesar $41,90 \%$. Tanaman genjer hanya mampu menurunkan suhu sebesar $15,74 \%$, sulfat sebesar $43,10 \%$ dan fosfat sebesar 31,98\%. Efisiensi pengurangan sulfat dan fosfat terjadi akibat penyerapan oleh akar, sehingga pengolahan dengan fitoremediasi akan mengurangi kadar sulfat dan fosfat di badan air penerima.

Hasil analisis juga menunjukkan bahwa telah terjadi perbaikan kualitas air limbah laundry setelah dilakukan pengolahan dengan penambahan tawas dan karbon aktif. Telah terjadi penurunan konsentrasi kulitas air dengan penambahan tawas dan karbon aktif tersebut dan dapat dilihat pada Tabel 8. Efisiensi penurunan terdiri dari : Suhu $(5,52 \%)$, Konduktivitas $(70,61 \%)$, BOD $(82 \%)$, COD $(81,39 \%)$, TSS $(92,25 \%)$, TDS $(76,72 \%)$, Deterjen $(57,72 \%)$ dan Fosfat $(92,28 \%)$.

Tabel 8 Hasil Analisis limbah cair laundry sebelum dan sesudah pengolahan

\begin{tabular}{l|c|c|c|c}
\hline \multirow{2}{*}{$\begin{array}{c}\text { Parameter } \\
\text { Kualitas Air }\end{array}$} & \multirow{2}{*}{ Satuan } & Sebelum & Setelah & $\begin{array}{c}\text { Hasil Analisis } \\
\text { penurunan } \\
(\%)\end{array}$ \\
\cline { 3 - 5 } & & & & - \\
\hline \hline $\mathrm{pH}$ & - & 6 & 6,50 & 5,52 \\
\hline Suhu & ${ }^{\circ} \mathrm{C}$ & 29 & 27,40 & 70,61 \\
\hline Konduktivitas & $\mu \mathrm{mhos} / \mathrm{cm}$ & 610 & 179,28 & 82,00 \\
\hline BOD & $\mathrm{mg} / \mathrm{L}$ & 150 & 27 & 81,39 \\
\hline COD & $\mathrm{mg} / \mathrm{L}$ & 231 & 43 & 92,25 \\
\hline TSS & $\mathrm{mg} / \mathrm{L}$ & 120 & 9,30 & 76,72 \\
\hline TDS & $\mathrm{mg} / \mathrm{L}$ & 309 & 71,94 & 57,72 \\
\hline Detergen & $\mathrm{mg} / \mathrm{L}$ & 4,21 & 1,78 & 92,28 \\
\hline Fosfat & $\mathrm{mg} / \mathrm{L}$ & 5,31 & 0,41 &
\end{tabular}

Sumber : Pratiwi dkk, 2012

Proses filter melalui aerasi kontak menggunakan media kayu arang, juga merupakan salah satu pengolahan air limbah deterjen yang pernah diteliti. Hasil menunjukkan, bahwa dengan konsentrasi awal 1,85 mg/L deterjen, terjadi penurunan konsentrasi setelah melewati sistem aerasi kontak dan semakin lama waktu pengamatan maka efisiensi penurunan konsentrasi deterjen semakin naik (Gambar 7).

Hari pertama efisiensi hanya $35,13 \%$ dan di hari yang ke 6 percobaan, efisiensi mencapai $72,97 \%$. Pada percobaan kedua yang dilakukan di hari yang ke 6 menunjukkkan efisiensi hari pertama mencapai 66,67\%, jauh lebih besar daripada efisiensi percobaan pertama. Sedangkan, hari ke - 11 (lima hari dari hari ke 6), efisiensi mencapai 90,95\%. Percobaan yang kedua menunjukkan efisiensi lebih besar di duga karena

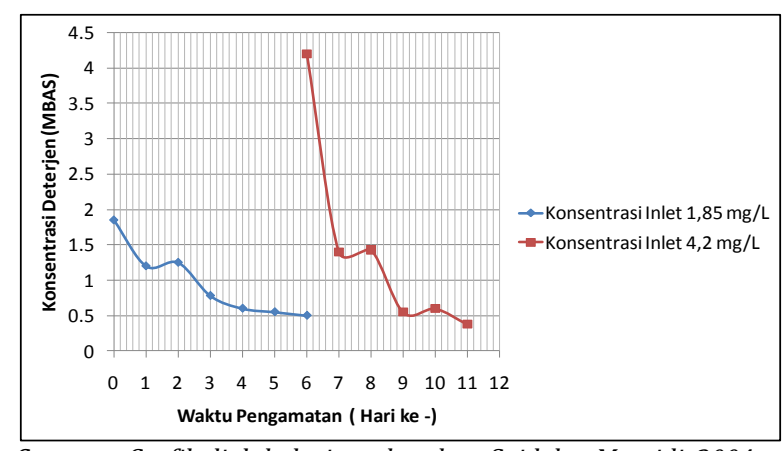

Catatan : Grafik diolah dari sumber data Said dan Marsidi, 2004

Gambar 7 Perubahan konsentrasi deterjen setelah beberapa hari pengolahan

Tabel 9 Prosentase penurunan konsentrasi kualitas air dengan filter keramik

\begin{tabular}{c|c|c|c|c|c|c}
\hline & $\begin{array}{c}\text { Komposisi } \\
\text { Filter } \\
\text { No }\end{array}$ & \multicolumn{5}{|c}{ \% Penurunan } \\
\cline { 3 - 7 } & $\begin{array}{c}\% \text { tanah liat }: \\
\% \text { zeolit : } \\
\% \text { serbuk besi })\end{array}$ & TDS & EC & COD & BOD $_{5}$ & $\begin{array}{c}\text { Linier } \\
\text { Alkyl } \\
\text { Sulfonat }\end{array}$ \\
\cline { 3 - 7 } & $72,5: 25: 2.5$ & 4,48 & 5,73 & 85,35 & 89,70 & 98,96 \\
\hline 2 & $67,5: 30: 2,5$ & 4,58 & 6,15 & 85,31 & 90,00 & 98,98 \\
\hline 3 & $77,5: 20: 2.5$ & 6,98 & 12,40 & 85,15 & 89,70 & 97,95 \\
\hline 4 & $69: 30: 01$ & 6,86 & 12,60 & 85,19 & 90,00 & 97,98 \\
\hline 5 & $74: 25: 01$ & 7,29 & 12,40 & 85,32 & 90,00 & 97,97 \\
\hline 6 & $70: 25: 05$ & 3,23 & 5,73 & 85,21 & 89,70 & 97,96 \\
\hline
\end{tabular}

Proses filter lainnya yang telah dikembangkan untuk mengendalikan limbah cair deterjen adalah filter keramik berbahan campuran tanah dan zeolit ( Nasir dan Budi, 2011), dapat dilihat pada tabel 9. Filter keramik menggunakan jenis bahan yaitu tanah liat, zeolit dan serbuk besi, diuji coba berdasarkan lima prosentase campuran (Tabel 9).

Hasil menunjukkan bahwa berbagai komposisi tersebut ternyata cukup efektif untuk menurunkan COD, BOD dan LAS. Komposisi filter tanah liat 77,5, zeolit 20 dan serbuk besi 2,5 \% dapat direkomendasikan karena cukup baik dalam mereduksi lima jenis parameter kualitas air tersebut.

Berdasarkan hasil - hasil penelitian tersebut diatas, untuk menjaga kualitas air di badan air termasuk lingkungan dan biota yang ada didalamnya, maka diperlukan upaya pengendalian limbah cair deterjen.

adanya bakteri pada media arang kayu sudah cukup beradaptasi dalam menurunkan deterjen ( Said dan Marsidi, 2004).

\section{Gagasan Teknik Pengendalian Pencemaran Deterjen Sederhana}

Penggunaan deterjen sebagai bahan pembersih sangat sulit dipisahkan dalam kehidupan sehari- 
hari, karena hampir semua orang menggunakannya misalnya untuk mencuci pakaian, seprei, gording, dll. Usaha meminimalisir dampak negatif deterjen terhadap lingkungan air baik biota maupun badan airnya, seharusnya dilakukan oleh semua orang. Penelitian ini mencoba untuk memberikan suatu gagasan teknik pengendalian pencemaran deterjen sederhana.

Gagasan teknik pengendalian pencemaran deterjen sederhana di latarbelakangi bahwa hampir seluruh rumah menghasilkan deterjen, sehingga diperlukan teknik individual untuk menanggulanginya. Gagasan pembuatan alat sederhana ini, dinamakan teknik penyaringan deterjen individu (TPDI), bisa dipasang di setiap rumah khususnya tempat pembuangan hasil cucian misalnya kamar mandi yaitu pada bagian bawah floordrain. Teknik filter pada TPDI (Gambar 8) didasarkan penelitian sebelumnya, bahwa tanpa adanya penyaringan/filter terhadap detergen akan berakibat buruk terhadap lingkungan baik biota maupun badan air. Detergen dapat menyebabkan toksisitas biota air pada badan air penerima (UcPeraza and Delgado-Blas,2012), komponen fosfat pada deterjen berkontribusi terhadap eutrofikasi pada badan air (Markina and Aizdaicher, 2007), penambahan konsentrasi di badan air tanpa pengolahan (filter) menyebabkan $\mathrm{pH}$ air menjadi basa, oksigen terlarut berkurang dan menaikkan suhu (Hermawati dkk, 2005). Penelitian lainnya, konsentrasi deterjen sebelum di filter 1,85 - 4,2 $\mathrm{mg} / \mathrm{L}$ setelah di filter meningkat menjadi $0,38-0,5$ $\mathrm{mg} / \mathrm{L}$, sehingga penggunaan filter ini diperkirakan dapat efektif untuk mengurangi deterjen di badan air penerima.

Spesifikasi TPDI yang dapat dilihat pada Gambar 8, terdiri dari : Bahan dasar PVC, tinggi 6 $\mathrm{cm}$ (menyesuaikan ketinggian dari floordrain sampai batas sekat pada pipa sambungan $\mathrm{T}$ yang ada pada pipa pembuangan dari kamar mandi), diameter 6,5 $\mathrm{cm}$ dan ketebalan $2 \mathrm{~mm}$ (menyesuaikan dengan diameter floordrain bagian bawah), bagian atas terbuka, bagian bawah berupa saringan untuk filter air limbah deterjen, bagian dalam berisi media kayu arang (karbon aktif) yang berfungsi untuk menyaring deterjen. TPDI dibuat dengan sistem bongkar pasang (knock down) sehingga mudah dalam pemeliharaan dan penggantian media karbon aktif dan dapat dilakukan oleh setiap individu.

Pemilihan Ide TPDI sebagai teknik filter didasarkan analisis bahwa dari penelitian sebelumnya teknik filter menghasilkan efisiensi pengolahan yang efektif. Fitoremediasi yaitu menggunakan tanaman kayu apu dan genjer (Hermawati dkk, 2005) menghasilkan efisiensi penyisihan terbesar hanya $41,90 \%$ pada parameter fosfat. Pengolahan kimia menggunakan tawas dan karbon aktif (Pratiwi dkk, 2012) walaupun efisiensi penyisihan fosfat tinggi sebesar $92,28 \%$ tetapi efisiensi peyisihan deterjen rendah yaitu sebesar 57,72\%. Teknik filter menghasilkan efisiensi yang tinggi yaitu filter melalui aerasi kontak menggunakan media kayu arang (Said dan Marsidi, 2004) mampu menurunkan konsentrasi deterjen hingga 90,95 \% dan filter keramik berbahan tanah liat dan zeolit (Nasir dan Budi, 2011) menurunkan konsentrasi BOD; COD; LAS masing - masing sebesar 89,70\%; 85,15\%; 97,95 $\%$.

Gagasan TPDI dibuat dengan menyesuaikan situasi rumah di Indonesia yang umumnya terdiri dari satu lantai, sehingga untuk rumah $>2$ lantai TPDI hanya dapat digunakan pada lantai dasar.

Media yang digunakan adalah kayu arang (karbon aktif) dengan pertimbangan harganya relatif terjangkau (murah), mudah didapat, efisiensi penyisihan cukup tinggi yaitu sebesar 90,95\% (Said dan Marsidi, 2004), serta mudah diganti dan dibersihkan.

Ide/gagasan pembuatan TPDI ini diharapkan dapat mengurangi beban limbah cair deterjen sejak dari sumbernya, sehingga pengaruh negatif terhadap lingkungan air baik biota maupun badan air dapat diminimalisir.

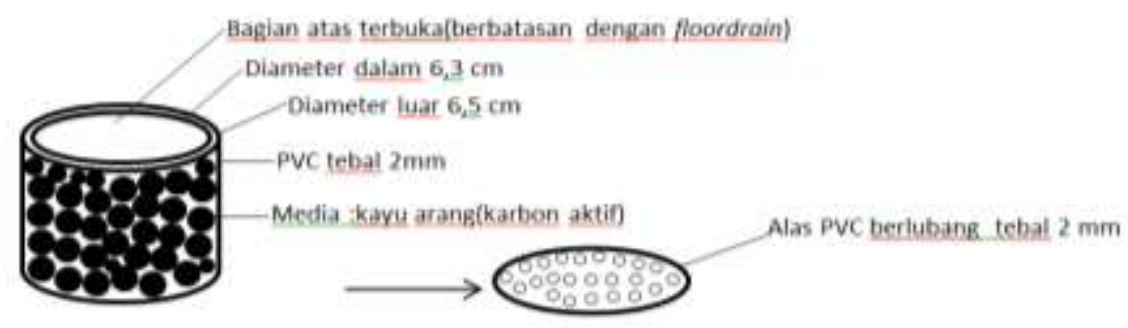

Gambar 8 Teknik Penyaringan Deterjen Individu (TPDI) 
Penanganan teknis dari sumber pencemar deterjen ini diharapkan dapat membuat lingkungan air bisa lebih dijaga, baik biota maupun badan airnya, karena dengan teknik ini minimal kualitas air limbah detergen setelah melewati TPDI mengalami perbaikan dan efek negatif dari limbah deterjen seperti toksisitas pada biota air dan eutrofikasi pada badan air dapat diminimalisir.

\section{KESIMPULAN}

Umumnya, model matematis yang merupakan hubungan antara banyaknya kematian biota air dengan waktu pengamatan dapat dinyatakan dengan persamaan polynominal orde dua. Model matematis ini untuk memberikan kemudahan perhitungan pengolahan angka atau pemodelan kematian biota air sebagai fungsi waktu kontak untuk berbagai konsentrasi air limbah sebagai efek toksisitas deterjen.

Kematian biota air akibat adanya deterjen pada badan air di duga disebabkan oleh kerusakan organ vital biota air (seperti ingsang, jantung, sel, dll) dan menurunnya kualitas air, sehingga pengolahan limbah cair deterjen sebagai upaya perbaikan atau penanggulangan sangat diperlukan. Alternatif upaya pengendalian yang telah ada dapat dilakukan melalui : fitroremediasi, pengolahan kimia, dan proses filter melalui media kayu arang maupun keramik.

Gagasan pembuatan teknik penyaringan deterjen individu (TPDI), dengan pertimbangan biaya pembuatan relatif murah dan operasi pemeliharaan cenderung mudah, selain diharapkan masyarakat bisa menerima dan memanfaatkan teknik ini, dan diharapkan juga akan mengurangi efek negatif deterjen pada lingkungan air baik biota maupun badan airnya.

\section{DAFTAR PUSTAKA}

Aini, N. 2013. Uji toksisitas detergen cair terhadap kelangsungan hidup benih ikan nila (Oreochromis niloticus). Skripsi Program Studi Manajemen Sumber Daya Perairan, Fakultas Pertanian, Universitas Sumatera Utara.

Arimoro F.O, Ikomi R.B., and Iwegblue C.M.A. 2007. Water quality changes in relation to dipteral community patterns and diversity measured at an organic effluent ampacted stream in the Niger Delta, Nigeria. Ecological Indicators 7(3): $541-552$.
Ath-thar, M.H.F., V.A. Prakoso, O.Z. Arifin dan R. Gustiano. 2010. Perfoma pertumbuhan ikan nila BEST pada berbagai media $\mathrm{pH}$. Prosiding Seminar Nasional Biologi UGM 2010 Yogyakarta. $4 \mathrm{hlm}$.

Barus, T.A. 2004. Pengantar limnologi studi tentang ekositem di daratan. Medan : USU Press.

Budiawan, Y.F., dan Neera, K. 2009. Optimasi biodegrabilitas dan uji toksisitas hasil degradasi surfaktan Linear Alkilbenzena Sulfonat (LAS) sebagai bahan detergen pembersih. Makara Sains 13(2): 125-133.

Chaerunisah dan R.N. Sopiah. 2006. Laju degradasi Surfaktan Linear Alkil Benzena Sulfonat (LAS) pada limbah detergen secara anaerob pada reaktor lekat diam biromedia sarang Tawon. Jurnal Teknologi Lingkungan 7(3): 243 - 250.

Fardhani, S.A., Yusli Wardiatno dan Majariana Krisanti. 2014. Perbandingan kelimpahan larva Chironomidae di dua danau berbeda di Provinsi Jambi. Jurnal Ilmu Pertanian Indonesia 19(3): 183 - 188

Garno, Y.S. 2000. Daya tahan beberapa organisme air pada pencemar limbah detergen. Jurnal Teknologi Lingkungan 1(3) : 212 -218.

Halang, B. 2004. Toksisitas air limbah detergen terhadap Ikan Mas. Bioscientiae 1(1) : 39 - 49.

Hardini, D.C., Yayat Dhahiyat dan Eddy Afrianto. 2012. Pengaruh konsentrasi pemaparan Surfaktan Alkyl Benzene Sulfonate terhadap toksisitas dan kerusakan jaringan Ikan Nila. Jurnal Perikanan dan Kelautan 3(1) : 59 - 63.

Heinrich M.L., Barnekov L, and Rosenberg S. 2006. A comparison of chironomid biostratigraphy from Lake Vuolep Njakajaure with vegetation, lake-level, and climate changes in Abisko National Park, Sweden. Journal of Paleolimnology 36(2): 119-131.

Henkel, M., Muller M.M., Kugler, J.H., Contiero, J., and Huasmana, R. 2012. Rhamnolipids as biosurfactants from renewable resources : concepts for next-generation rhamnolipid production. Process Biochem 47(8) : 1207 1219.

Hermawati, E., Wiryanto, dan Solichatun. 2005. Fitroremediasi limbah detergen menggunakan Kayu Apu (Pistia stratiotes L.) dan Genjer (Limnochoris flava L). Biosmart 7(2) : 115 124. 
IMRG. 2012. Synthetic detergents and cleaning products in the CIS and Baltic Countries: production, market and forecast. Info Mine Market Research Group. http://www.infomine.ru/files/catalog/166/file _166_eng.pdf(diakses tanggal 25 Desember 2015).

Lubis, Siti Devi Permata Sari., Budi Utomo dan Riri Ezraneti. 2014. Uji detergen terhadap Ikan Mas. Jurnal Aquacoastmarine 4(3): 69-75.

Markina, Z.V., and Aizdaicher, N.A. 2007. Influence of laundry detergents on the abundance dynamics and physiological state of benthic microalga Attheya ussurensis (Bacillariphyta) in laboratory culture. Russ J Mar Biol 33(6): 391398.

Nasir, S dan Budi, T. 2011. Pengolahan air limbah hasil laundry menggunakan filter keramik berbahan campuran tanah liat dan zeolit. Laporan Penelitian Hibah Kompetitif 2. Indralaya : Universitas Sriwijaya.

Nugroho, A. 2006. Bioindikator kualitas air. Jakarta : Universitas Trisakti

Noviantoro, A. Agung Sudaryono dan Ristiawan Agung Nugroho. 2015. Pengaruh pemberian Omega-3 dan Klorofil dalam pakan terhadap fekunditas dan derajat penetasa benih ikan nila (Oreochromis niloticus). Jurnal of Aquaculture Management and Technology 4(4) : 95 - 100

Odume O.N., and Muller W.J. 2011. Diversity and structure of Chironomidae communities in relation too water quality differences in the Swartkops River. Elsevier. Aquaculture 36: 929 938.

Pratiwi, Y, Sri Sunarsih dan Winda Febria Windi. 2012. Uji toksisitas limbah cair laundry sebelum dan sesudah diolah dengan tawas dan karbon aktif terhadap bioindikator (Cyprinuscarpio L). In Prosiding Seminar Nasional Aplikasi Sains \& Teknologi (SNAST) Periode III, A-208 - 306, ISSN : 1979-911X. Yogyakarta, 3 November 2012.

Putranti, G.P., Subandiyono dan Pinandoyo. 2015. Pengaruh protein dan energi yang berbeda pada ikan pakan buatan terhadap efisien pemanfaatan pakan dan pertumbuhan ikan mas (Cyprinus carpio). Jurnal of Aquaculture Managemnet and Technology 4(3) : 38-45.

Said, N.I dan R. Marsidi. 2004. Proses "aerasi kontak" menggunakan media arang kayu untuk mengurangi detergen dalam air baku. Jurnal Teknologi Lingkungan 5(2) : 96 - 102.
Shafruddin, D, B.R. Parlinggoman dan K. Sumantadinata. 2006. Pertumbuhan dan produksi larva cacing darah Chironomus sp. pada media yang dipupuk kotoran ayam Dosis 1,0 - 2,5 Gram/Liter. Jurnal Akuakultur Indonesia 5(1) : 97 - 102.

Sinar Harapan. 2015. Air baku PDAM ikut tercemar : produksi air bersih terpaksa diturunkan. http://www.sinarharapan.co/news/read/1511 03545/air-baku-pdam-ikut-tercemr-,03 November 2015, 11:25 (diakses tanggal 24 Desember 2015).

Sugiyono. 2011. Metode penelitian kuantitatif dan kualitatif dan R \& D. Bandung : Alfabeta.

Smulders, E. 2002. Laundry Detergents. Weinheim, Germany : Wiley-VCH Verlag $\mathrm{GmbH}$.

Tang, M. dan V. Suendo. 2011. Pengaruh Penambahan Pelarut Organik Terhadap Tegangan Permukaan Larutan Sabun. Prosiding Simposium Inovasi Pembelajaran dan Sains 2011(SNIPS 2011), 22-23 Juni 2011, Bandung, Indonesia.

Uc-Peraza, R.G., and Degado-Blas, V.H. 2012. Determinacion de la concentraction letal media (CL50) de cuarto detergents domesticos biodegradables en Laeoneries culveri (Webster, 1879) (Polychaeta, Annelida). Rev Int. Contam Ambient 28(2): 137 - 144.

Uc-Peraza, R.G., and Degado-Blas, V.H. 2015. Acute toxicity and risk assessment of tree commercial detergents using the polychaete Capitella sp. C from Chetumal Bay, Quintana Roo, Mexico . Rev Aquat Res. 7: 251 - 261. DOI 10.1007/s4007-015-0112-z.

Yudo, S. 2010. Kondisi kualitas air Sungai Ciliwung di wilayah DKI Jakarta ditinjau dari parameter Organik, Amoniak, Fosfat, Detergen dan Bakteri Coli. Jurnal Air Indonesia 6(1) : 34 - 42.

\section{UCAPAN TERIMA KASIH}

Ucapan terima kasih disampaikan kepada Dewan Redaksi dan Mitra Bestari atas koreksi tulisannya, sehingga tulisan ini dapat dipublikasi. 